Article

\title{
Cyclic Octamer Peptoids: Simplified Isosters of Bioactive Fungal Cyclodepsipeptides
}

\author{
Assunta D'Amato ${ }^{1}$, Giorgio Della Sala ${ }^{1}$ (1) , Irene Izzo ${ }^{1}$ (D), Chiara Costabile ${ }^{1}$, Yuichi Masuda ${ }^{2, *}$ \\ and Francesco De Riccardis $1, *$ (D) \\ 1 Department of Chemistry and Biology “A. Zambelli”, University of Salerno, Via Giovanni Paolo II, 132, \\ 84084 Fisciano, Italy; asdamato@unisa.it (A.D.); gdsala@unisa.it (G.D.S.); iizzo@unisa.it (I.I.); \\ ccostabile@unisa.it (C.C.) \\ 2 Graduate School of Bioresources, Mie University, 1577 Kurimamachiya-cho, Tsu 514-8507, Japan \\ * Correspondence: masuda@bio.mie-u.ac.jp (Y.M.); dericca@unisa.it (F.D.R.); \\ Tel.: +81-59-231-9620 (Y.M.); +39-089-969-552 (F.D.R.)
}

Received: 6 July 2018; Accepted: 14 July 2018; Published: 19 July 2018

\begin{abstract}
Cyclic peptoids have recently emerged as an important class of bioactive scaffolds with unique conformational properties and excellent metabolic stabilities. In this paper, we describe the design and synthesis of novel cyclic octamer peptoids as simplified isosters of mycotoxin depsipeptides bassianolide, verticilide A1, PF1022A and PF1022B. We also examine their complexing abilities in the presence of sodium tetrakis[3,5-bis(trifluoromethyl)phenyl]borate (TFPB) salt and explore their general insecticidal activity. Finally, we discuss the possible relationship between structural features of free and $\mathrm{Na}^{+}$-complexed cyclic octamer peptoids and bioactivities in light of conformational isomerism, a crucial factor affecting cyclic peptoids' biomimetic potentials.
\end{abstract}

Keywords: cyclic peptoids; cyclodepsipeptides; insecticidal activity; conformational isomerism; structure-based design; peptidomimetics

\section{Introduction}

While the vast inventory of natural products finds its limits in the finiteness of biosynthetic pathways [1], the synthesis of non-natural analogues has no boundaries [2]. For their distinct conformational properties [3], their excellent biostabilities [4] and straightforward modular construction [5], peptoids (i.e., oligomers of $\mathrm{N}$-substituted glycines) [6] represent a formidable class of biomimetic compounds with striking bio- and pharmacological activities $[7,8]$.

Among peptoid oligomers, cyclic peptoids hold a special status for their intrinsic ability to adopt compact folded conformations $[9,10]$ and exhibit conspicuous therapeutic properties $[9,11]$. Their excellent biomimetic properties have been confirmed by a recent study in which abiotic hexamer cyclopeptoids (mimicking depsipeptide mycotoxins of the enniatins class) evoked potent cytotoxic activities against cancer cell lines [12].

In the present contribution, we report the design and synthesis of structural congeners of cyclic octamer depsipeptides bassianolide (Bs, 1) [13,14], verticilide A1 (VtA1, 2) [15,16] and PF1022A/PF1022B (3 and 4, respectively, Figure 1) [17-20]. In this investigation, we will evaluate both the advantages and drawbacks related to the use of cyclic peptoids as natural products mimics.

Peptoid congeners 5-8 (Figure 1) were obtained replacing the $\alpha$-amino/hydroxy acids methines and intraannular $\mathrm{N} / \mathrm{O}$ atoms present in natural cyclodepsipepides with nitrogen atoms and methylene groups, respectively. $\mathrm{N}$-methyl substituents of L-leucine/alanine residues were removed in order to have a sequence of $N$-alkyl glycines. The relative position of the carbonyl groups was left unaltered to preserve possible metal chelating properties, essential for biological activities [14,20-23]. 


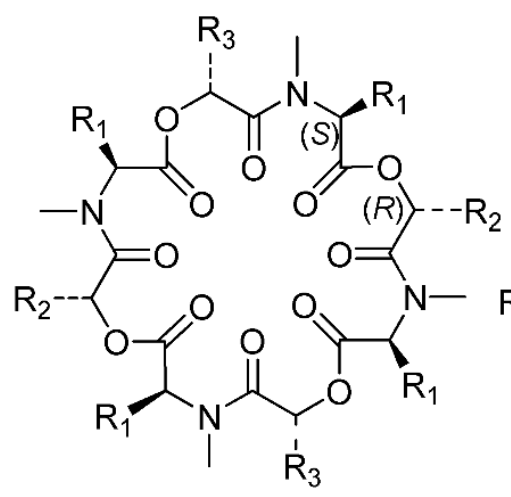

Cyclic octamer depsipeptides

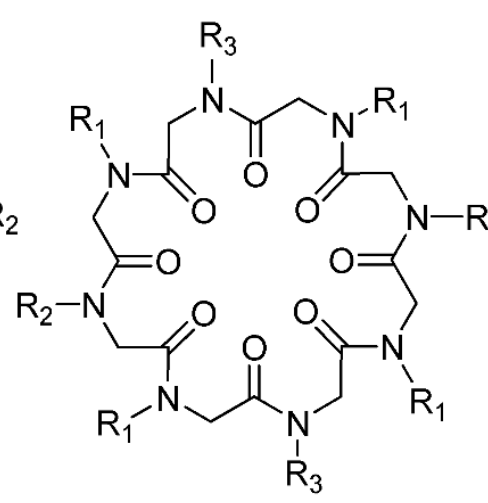

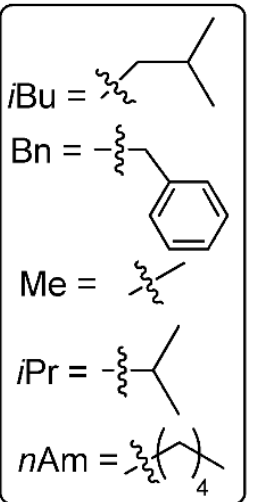

Cyclic peptoids

\begin{tabular}{ccccc}
\hline OCDs & Cyclic Peptoid Congeners & $\mathbf{R}^{1}$ & $\mathbf{R}^{2}$ & $\mathbf{R}^{3}$ \\
\hline Bassianolide (Bs, 1) & 5 & $i \mathrm{Bu}$ & $i \mathrm{Pr}$ & $i \mathrm{Pr}$ \\
PF1022A (2) & $\mathbf{6}$ & $i \mathrm{Bu}$ & $\mathrm{Bn}$ & $\mathrm{Me}$ \\
PF1022B (3) & 7 & $i \mathrm{Bu}$ & $\mathrm{Bn}$ & $\mathrm{Bn}$ \\
Verticilide A1 (Vt, 4) & 8 & $\mathrm{Me}$ & $n \mathrm{Am}$ & $n \mathrm{Am}$ \\
\hline
\end{tabular}

Figure 1. Natural octamer cyclic depsipeptides (OCDs) mycotoxins (1-4) and cyclic peptoid congeners (5-8) synthesized in the present paper.

The depsipeptide/peptoid core switch yields congeners fully compatible with the solid-phase synthesis. Moreover, starting materials are inexpensive and the availability of hundreds of primary amines allows extensive structure-activity investigations.

On simplified isosters 5-8 general insecticidal assays on 4th-instar silkworm larvae $[24,25]$ have been evaluated.

\section{Results and Discussion}

\subsection{Chemistry and Conformational Studies}

The syntheses of cyclic octamer peptoids 5-8 began with the solid-phase "submonomer" construction of linear precursors 9-12 (Table 1) [5]. N,N'-diisopropylcarbodiimide-induced bromoacetic acid condensations were alternated with amine substitutions until formation of the desired linear oligomeric amides. Detachment from the acid-labile solid support in the presence of hexafluoroisopropanol yielded octamers in acceptable to good yields and decent purities (Table 1).

Table 1. Solid-phase synthesis of linear peptoids 9-12: sequences, mass data (ESI/MS), chemical yields and purity.

\begin{tabular}{cccc}
\hline Sequence $^{\text {a }}$ (Oligomer) & ESI/MS & Yield & Purity \\
\hline H-[NVal-NLeu $]_{4}-\mathrm{OH}(\mathbf{9})$ & $867.5[\mathrm{M}+\mathrm{H}]^{+}$ & $100 \%$ & $82 \%$ \\
H-[NPhe-NLeu-NAla-NLeu $]_{2}-\mathrm{OH}(\mathbf{1 0})$ & $908.2[\mathrm{M}+\mathrm{H}]^{+}$ & $49 \%$ & $92 \%$ \\
H-[NPhe-NLeu $]_{4}-\mathrm{OH}(\mathbf{1 1})$ & $1059.6[\mathrm{M}+\mathrm{H}]^{+}$ & $89 \%$ & $71 \%$ \\
H-[Nam-NAla $]_{4}-\mathrm{OH}(\mathbf{1 2})$ & $811.5[\mathrm{M}+\mathrm{H}]^{+}$ & $100 \%$ & $83 \%$ \\
\hline
\end{tabular}

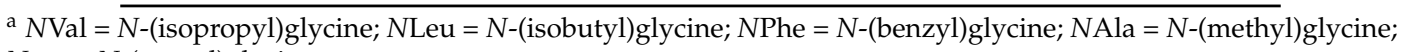
$\mathrm{Nam}=\mathrm{N}$-(pentyl)glycine. 
Head-to-tail cyclisations of crude linear peptoids 9-12 were performed in high dilution conditions (3.0 $\mathrm{mM}$ concentration) in the presence of HATU as the coupling agent [26]. Cyclic compounds were purified from traces of unreacted/oligomerized linear peptoids through precipitation from hot acetonitrile (in the case of 5 and 7) or reverse-phase column chromatography (oligomers 6 and 8 ). Cyclic oligoamides 5-8 were isolated as white amorphous solids (purity $>$ 98\%, HPLC analysis).

Despite their large size, the mycotoxins' congeners showed good conformational stabilities $\left({ }^{1} \mathrm{H}\right.$ NMR analysis, Figure 2). In particular, cyclopeptoids with $\beta$-branched $N$-side chains (5-7) exhibited single dominant conformers $\left(>85 \%,{ }^{1} \mathrm{H}\right.$ NMR analysis, Figure $\left.2 \mathrm{a}-\mathrm{c}\right)$, while $N$-methyl/amyl substituted 8 displayed multiple conformations in slow equilibrium on the NMR time scale (Figure 2d).

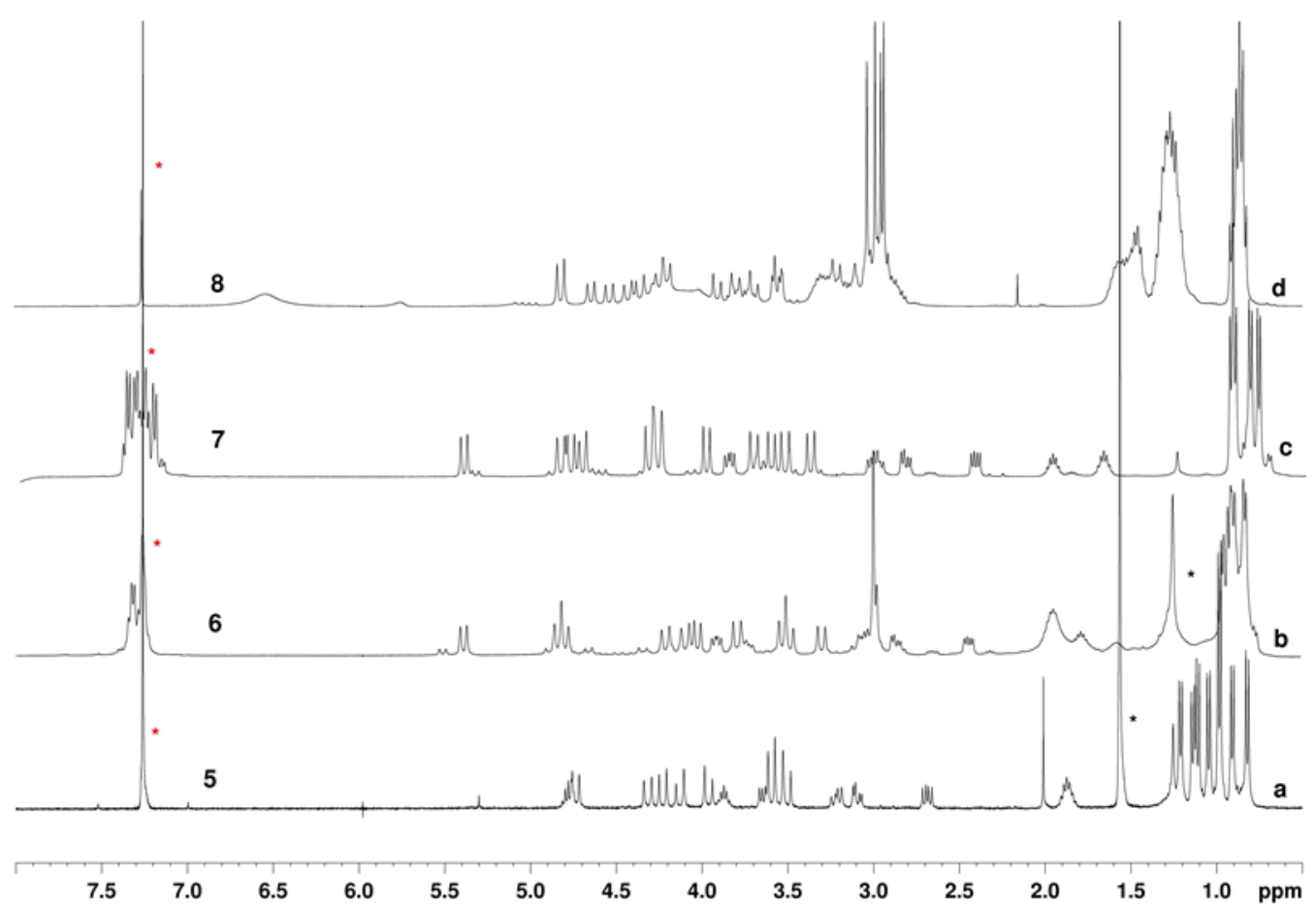

Figure 2. ${ }^{1} \mathrm{H}$ NMR spectra of cyclic peptoids 5-8. $5.0-10.0 \mathrm{mM}$ solutions in $\mathrm{CDCl}_{3}(400 \mathrm{MHz})$. Residual solvent peaks are labelled with a red asterisk. $\mathrm{H}_{2} \mathrm{O}$ and further $\mathrm{CDCl}_{3}$ impurities are labelled with a black asterisk.

Conformational interconversion barriers have been quantified by variable-temperature (VT) ${ }^{1} \mathrm{H}$ NMR experiments for conformationally homogeneous 5-7. Coalescence temperatures were experimentally determined to be $110{ }^{\circ} \mathrm{C}\left(\mathrm{C}_{2} \mathrm{D}_{2} \mathrm{Cl}_{4}, \Delta \mathrm{G}^{\ddagger}=17.4 \pm 0.9 \mathrm{kcal} / \mathrm{mol}, 300 \mathrm{MHz}\right), 90{ }^{\circ} \mathrm{C}$ $\left(\mathrm{C}_{2} \mathrm{D}_{2} \mathrm{Cl}_{4}, \Delta \mathrm{G}^{\ddagger}=15.9 \pm 0.8 \mathrm{kcal} / \mathrm{mol}, 300 \mathrm{MHz}\right)$ and $90{ }^{\circ} \mathrm{C}\left(\mathrm{C}_{2} \mathrm{D}_{2} \mathrm{Cl}_{4}, \Delta \mathrm{G}^{\ddagger}=16.4 \pm 0.8 \mathrm{kcal} / \mathrm{mol}\right.$, $300 \mathrm{MHz}$ ) for cyclopeptoids 5, 6 and 7, respectively. No conformational stability studies have been reported for octamer cyclodepsipeptides in that, in most of the deuterated solvents, bassianolide [14], PF1022A [15,27] and verticilide A1 [28] are present as complex mixtures of conformers in slow equilibrium on the NMR time scale.

2D homonuclear (COSY) and heteronuclear (HMQC, HMBC) experiments allowed assignment of the ${ }^{1} \mathrm{H} /{ }^{13} \mathrm{C}$ resonances for cyclic peptoids 5-7, suggesting formation of $C_{2}$-symmetric ccttcctt species for 5 and 7 (half of the signals were present in the NMR spectra, as previously reported for octamer peptoids [29-34]) and a $C_{1}$-symmetric species for 6 . Peptoid bond geometries have been documented by ${ }^{1} \mathrm{H}$ NMR chemical shifts values. In particular, relatively low values for $\mathrm{C} \alpha-\mathrm{H} N$-side chains' or small $\Delta \delta$ for diastereotopic $\mathrm{C} \alpha-\mathrm{H}_{2}$ testified for trans peptoid junctions; higher values of chemical shifts or larger $\Delta \delta$ were indicative of $c$ is amide bonds [12]. The NMR data identified two possible alternative structures for symmetric 5 and 7 . In these congeners two of the four isobutyl/isopropyl and benzyl 
side chains were located on cis amide bonds and the other two were on trans peptoid junctions $(\mathbf{5 a} / \mathbf{5} \mathbf{b}$ and $\mathbf{7 a} / \mathbf{7 b}$, Figure 3, see also Figure S2 of Supplementary Material).

Accurate analysis of the ${ }^{1} \mathrm{H}$ NMR resonances showed no symmetry elements for compound 6 (to the best of our knowledge, this is the first case of symmetry breaking in the case of a conformationally stable, symmetrically substituted, cyclic octamer peptoid) (see experimental part and Figure S2 of Supplementary Material). The presence of two $N$-benzyl and two $N$-isobutyl side chains on cis amide bonds, plus two $\mathrm{N}$-isobutyl and two $\mathrm{N}$-methyl side chains on trans peptoid junctions testified for the asymmetric arrangement of cyclic oligomer 6 .

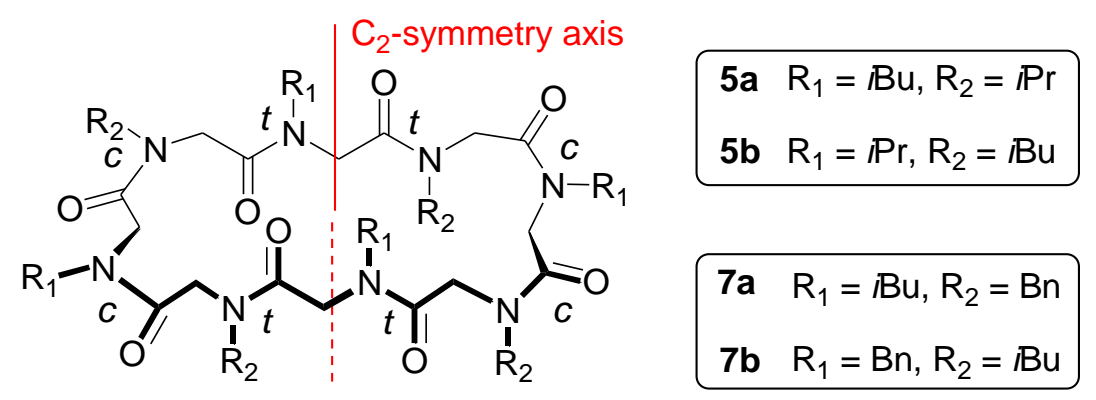

Figure 3. Schematic structure of the possible conformational diastereoisomers for cyclic peptoids $\mathbf{5}$ and $\mathbf{7 .}$

$C_{2}$-symmetric ccttcctt-conformational diastereoisomers $5 \mathbf{a} / \mathbf{b}$ and $7 \mathbf{a} / \mathbf{b}$ were modelled by DFT (Density Functional Theory) studies and minimum energy structures were located in order to find the plausible most stable conformations. Free energies in $\mathrm{CHCl}_{3}$ have been reported in Figure 4 (see S.M. for computational details). Isomers $\mathbf{5 a}$ and $\mathbf{7 b}$ were found to be more stable than the corresponding conformational diastereoisomers $5 \mathbf{b}$ and $7 \mathbf{a}$ of 2.2 and $0.8 \mathrm{kcal} / \mathrm{mol}$, respectively. The energy differences are mainly due to steric interactions among the $\mathrm{N}$-substituents and the ring. More in detail, as reported in Figure 4, $\mathbf{5} \mathbf{b}$ shows isobutyl-ring distances shorter than $\mathbf{5 a}$, whereas interactions among the phenyl groups and the ring is responsible for the higher energy of $7 \mathbf{a}$ with respect to $\mathbf{7 b}$. Furthermore, the higher energy difference between $5 \mathbf{a}$ and $5 \mathbf{b}(2.2 \mathrm{kcal} / \mathrm{mol})$ could explain why the NMR spectrum of 5 shows only one conformational isomer, whereas the ${ }^{1} \mathrm{H}$ NMR spectrum of $\mathbf{7}$ shows a small amount of the other isomer (Figure 2c). These data are also concordant with the VT-experiments (the coalescent temperature and therefore the conformational interconversion barrier, is higher for cyclopeptoid 5). 

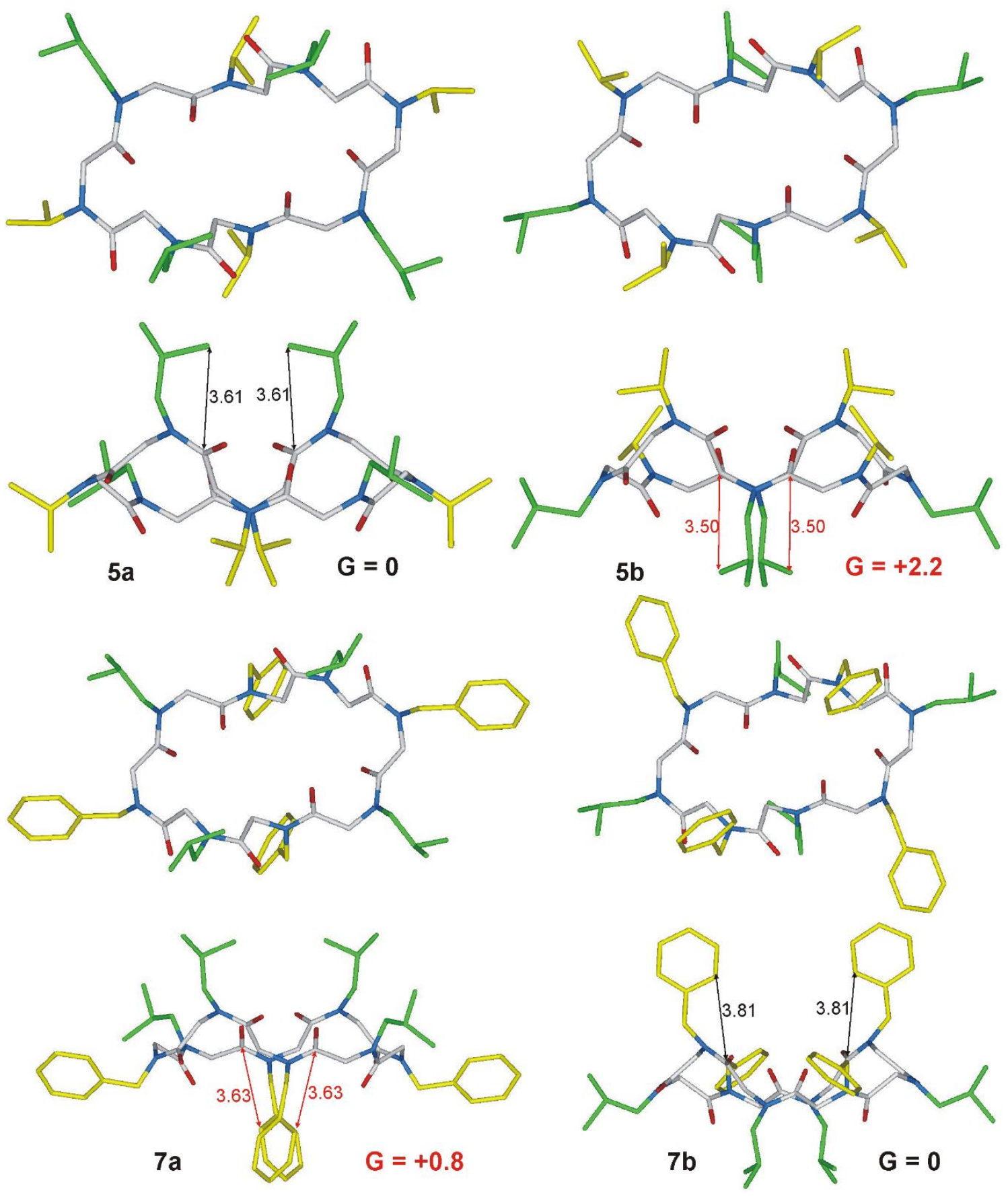

Figure 4. Top and side view of minimum energy structures of conformational diastereisomers $\mathbf{5 a} / \mathbf{b}$ and $7 \mathbf{a} / \mathbf{b}$. For the sake of clarity isobutyl groups are reported in green, whereas isopropyl and benzyl groups in yellow. Free energies were calculated in $\mathrm{CHCl}_{3}$ and reported in $\mathrm{kcal} / \mathrm{mol}$. Distances are reported in $\AA$.

It is interesting to note that the removal of two phenyl groups in compounds $\mathbf{6}$ (where two $\mathrm{N}$-methyl groups take the place of two $\mathrm{N}$-benzyl side chains in 7) causes a profound effect on the intrinsic stability of the cyclopeptoid framework and breaks the symmetry of the octameric species.

Another important aspect regarding the conformational isomerism of rigid cyclic octamer peptoids is related to their conformational chirality [10].

The presence of a $C_{1}$ - or $C_{2}$-symmetry axis and the relatively high barrier for conformational inversion of the cyclooligomeric species $\left(\Delta \mathrm{G}^{\ddagger} \geq 10 \mathrm{kcal} / \mathrm{mol}\right)$ makes cyclic peptoid 5-7 chiral 
and observable as conformational enantiomers in solution by NMR spectroscopy (which, at room temperature, reveals species with lifetimes exceeding $10^{-2} \mathrm{~s}$ ) [10].

The presence of enantiomorphic conformers was demonstrated by step-wise addition of Pirkle's alcohol ((R)-1-(9-anthryl)-2,2,2-trifluoroethanol) [35] to a $\mathrm{CDCl}_{3}$ solution of representative cyclopeptoid 7 (Figure 5). Extensive signal splitting (marked with red asterisks) confirmed the presence in solution of both enantiomers $7 \mathbf{b} / 7 \mathbf{c}$.

\subsection{Complexation Studies}

The biological action of CDPs is often associated to the formation of metal complexes [18-20]. We therefore tested the metal chelating attitudes of cyclic peptoids 5-8 in the presence of sodium tetrakis[3,5-bis(trifluoromethyl)phenyl]borate (NaTFPB, [12]) in $\mathrm{CDCl}_{3}$ solutions $\left({ }^{1} \mathrm{H}\right.$ NMR analysis, Figure 6). In all the performed experiments the presence of two equivalents of $\mathrm{Na}^{+}$cation induced formation of highly symmetric metalated species in slow equilibrium with the corresponding free hosts on the NMR time scale. Addition of one equivalent of NaTFPB showed the formation of a mixture of multiple complexes in slow equilibrium on the NMR time scale. Two equivalent of cationic guest established the formation of single detectable, highly symmetric, complexes. The relatively low chemical shift values observed for the NAla $\left(2.85 \mathrm{ppm}\right.$ in $[6 \cdot 2 \mathrm{Na}]^{2+} ; 2.88 \mathrm{ppm}$ in $\left.[8 \cdot 2 \mathrm{Na}]^{2+}\right)$ and $N$ Val $\left(3.96 \mathrm{ppm}\right.$ in $\left.[5 \cdot 2 \mathrm{Na}]^{2+}\right) \mathrm{C} \alpha \mathrm{H}$ resonances; the small $\Delta \delta$ evidenced for the diastereotopic $-\mathrm{N}-\mathrm{CH}_{2}-\mathrm{CH}\left(\mathrm{CH}_{3}\right)_{2}$ protons of $\mathrm{NLeu}\left(0.22 \mathrm{in}[5 \cdot 2 \mathrm{Na}]^{2+} ; 0.30\right.$ in $\left.[6 \cdot 2 \mathrm{Na}]^{2+}\right),-\mathrm{N}-\mathrm{CH}_{2}-\mathrm{Ph}$ protons of NPhe $\left(0.48\right.$ in $[6 \cdot 2 \mathrm{Na}]^{2+} ; 0.51$ in $\left.[7 \cdot 2 \mathrm{Na}]^{2+}\right)$ and $-\mathrm{N}^{-} \mathrm{CH}_{2}-\left(\mathrm{CH}_{2}\right)_{3}-\mathrm{CH}_{3}$ protons of $\mathrm{Nam}\left(0.23\right.$ in $\left.[8 \cdot 2 \mathrm{Na}]^{2+}\right)$ residues suggested, for all the cyclic octamers, all-trans peptoid junctions [36].

The host/guest ratio (calculated integrating the signals of the host/guest complex respect to those of dissolved guest, NaTFPB) remained constant during all the titration experiments and documented a 1:2 macrocycle $/ \mathrm{Na}^{+}$ratio for all the synthesized complexes. The apparent association constants were therefore calculated for the formation of the $[5-8 \cdot 2 \mathrm{Na}]^{2+}$ species by ${ }^{1} \mathrm{H} \mathrm{NMR}\left(1.0 \mathrm{mM}, \mathrm{CDCl}_{3}\right)[37,38]$ showing similar values for all the bimetallic adducts $\left(\mathrm{K}_{\mathrm{a}}:[5 \cdot 2 \mathrm{Na}]^{2+}: 1.9 \cdot 10^{7} \mathrm{M}^{-2},[6 \cdot 2 \mathrm{Na}]^{2+}: 7.2 \cdot 10^{6}\right.$ $\left.\mathrm{M}^{-2},[7 \cdot 2 \mathrm{Na}]^{2+}: 1.9 \cdot 10^{6} \mathrm{M}^{-2},[8 \cdot 2 \mathrm{Na}]^{2+}: 1.3 \cdot 10^{7} \mathrm{M}^{-2}\right)$. VT ${ }^{1} \mathrm{H}$ NMR experiments indicated no sign of coalescence up to $110^{\circ} \mathrm{C}\left(\mathrm{C}_{2} \mathrm{D}_{2} \mathrm{Cl}_{4}, 600 \mathrm{MHz}\right)$. The efficient ion-dipole interactions between the carbonyl groups and the sodium cation increases the conformational stabilities of the macrorings.

Also, the $\mathrm{Na}^{+}$-complexes were present as couples of enantiomorphous cyclooligomers (Figure 7). In particular, cyclic peptoids $[5 \mathbf{c} \cdot 2 \mathrm{Na}]^{2+}$ and $[5 \mathbf{d} \cdot 2 \mathrm{Na}]^{2+}$, showing alternating side chains, are $\mathrm{C}_{4}$-symmetric conformational enantiomers; macrorings $[6 \mathbf{6} \cdot 2 \mathrm{Na}]^{2+}$ and $[6 \mathbf{b} \cdot 2 \mathrm{Na}]^{2+}$ are $C_{2}$-symmetric species and 7 and 8 (not reported), with alternating side chains, form couples of $C_{4}$-symmetric conformational enantiomers. 

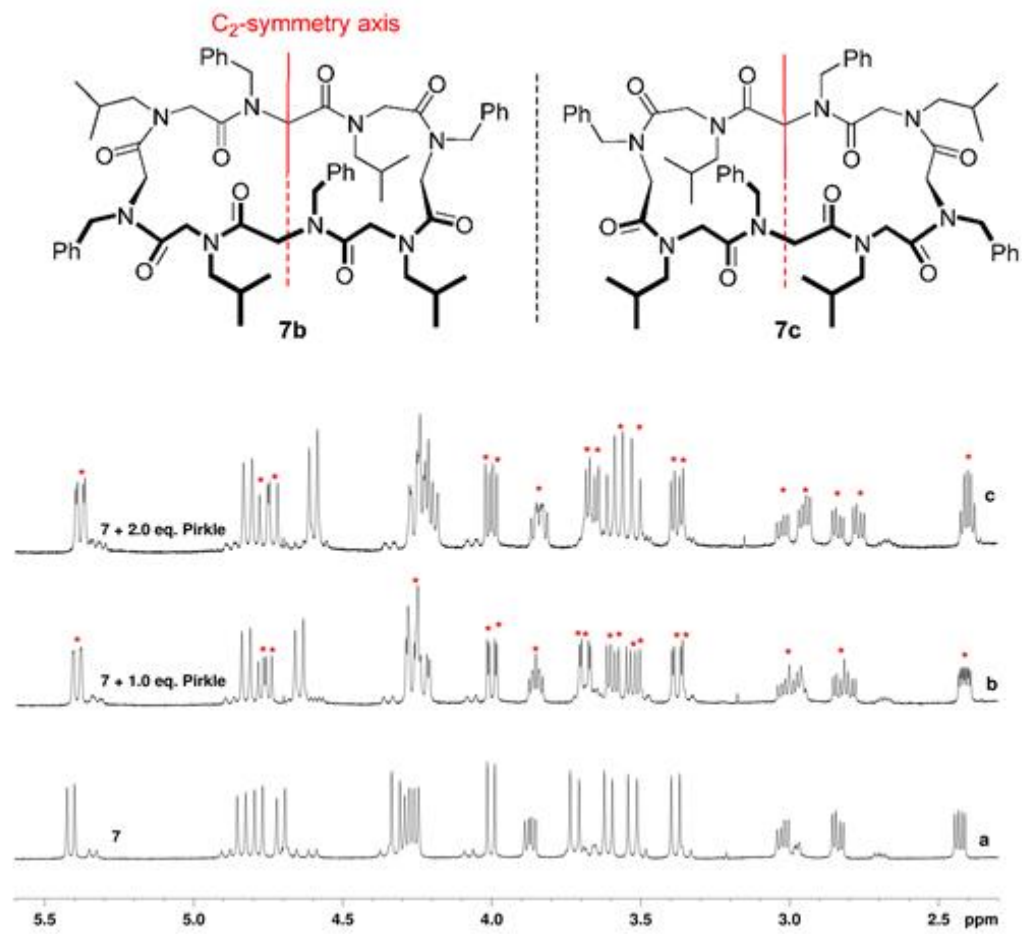

Figure 5. ${ }^{1} \mathrm{H}$ NMR spectra resulting from the quantitative step-wise addition of Pirkle's alcohol to the $5.0 \mathrm{mM}$ solution in $\mathrm{CDCl}_{3}(600 \mathrm{MHz})$. Red asterisks denote split signals.
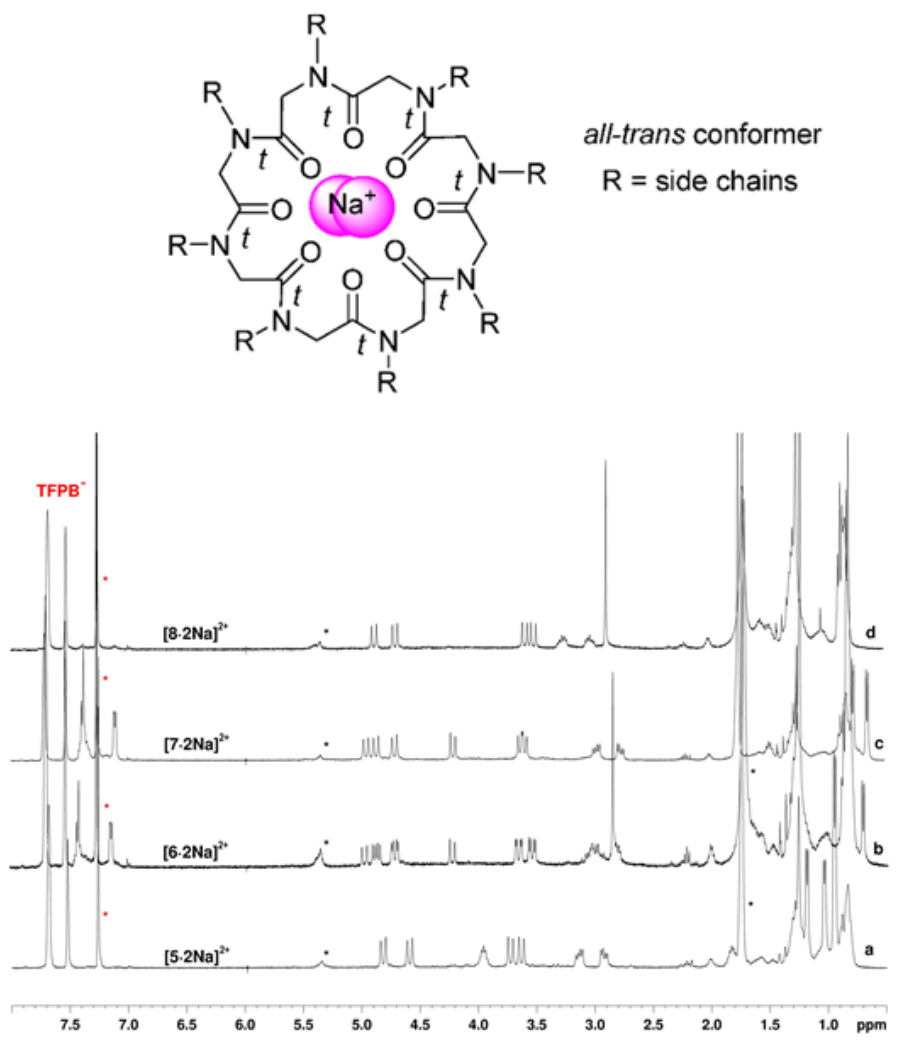

Figure 6. ${ }^{1} \mathrm{H}$ NMR spectra showing $\left[\begin{array}{ll}5-8 & 2 \mathrm{Na}\end{array}\right]^{2+}$ complexes and general structure of the highly symmetric all-trans core conformer. Residual solvent peaks are labelled with a red asterisk. $\mathrm{H}_{2} \mathrm{O}$ and further $\mathrm{CDCl}_{3}$ impurities are labelled with a black asterisk. $1.0 \mathrm{mM}$ host solutions in the presence of 2.0 equivalents of NaTFPB in $\mathrm{CDCl}_{3}(400 \mathrm{MHz})$. 

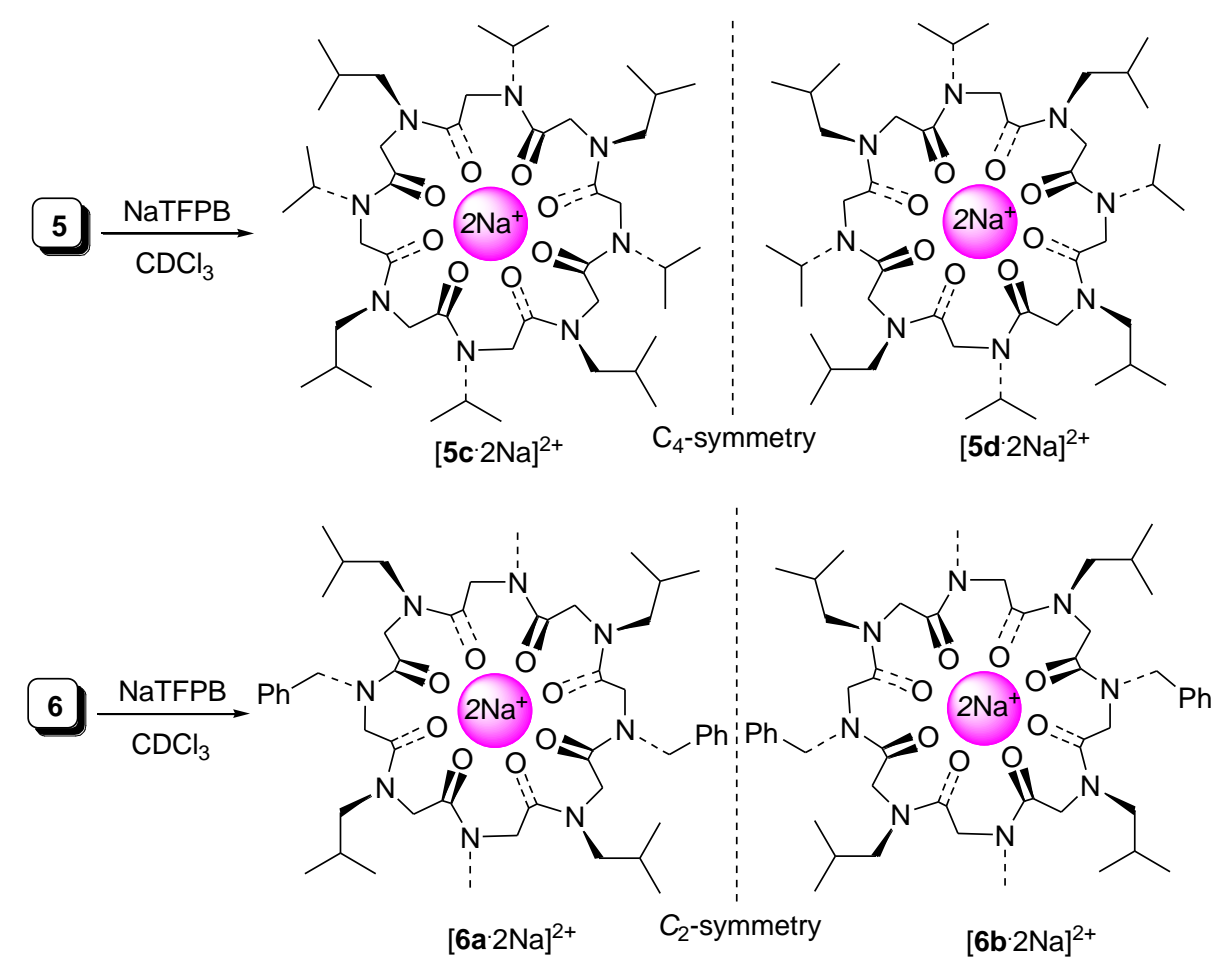

Figure 7. Schematic structures of both the enantiomers of all-trans $\mathrm{Na}^{+}$-complexes of cyclic octamer peptoids 5 and 6 . $C_{4}$-symmetric $[5 \mathrm{c} \cdot 2 \mathrm{Na}]^{2+} /[\mathbf{5 d} \cdot 2 \mathrm{Na}]^{2+}$ and $C_{2}$-symmetric $[6 \mathbf{6 a} \cdot 2 \mathrm{Na}]^{2+} /[\mathbf{6 b} \cdot 2 \mathrm{Na}]^{2+}$ are non-superimposable mirror images. Amide bonds are considered as rigid planes.

Formation of conformational enantiomers in rigid octamer cyclopeptoids as free hosts or complexes represents a crucial factor to predict/interpret their biological action. It should be noted that the presence of enantiomorphous species is not detrimental to the biological activity only when the biological target is not chiroselective (as in the case of the cell membrane) [39]. Things change dramatically when the target of biological action is a chirospecific receptor (proteins, carbohydrates or nucleic acids).

In the case of enniatin A and B, both enantiomers are bioactive [40] (cyclic hexadepsipeptides, in fact, interfere with the cations' transport through the membrane). Studies on the molecular action of octamer depsipetides indicate specific molecular targets for these molecules. It is known for example, that PF1022A acts on the latrophin-like receptor and on the $\mathrm{Ca}^{2+}$-activated $\mathrm{K}^{+}$channel [20]. Verticilide A1 has been shown to bind selectively to the insect ryanodine receptor, a major target for modern insecticides [15] and it efficiently inhibits the acyl-CoA cholesterol acyltransferases ACAT1 and ACAT2 [41]. Emodepside, a broad spectrum anthelmintic cyclooctadespispetide derived from PF1022A [21], has multiple molecular targets. On the basis of these considerations, it is clear that the presence of stable free and complexed conformationally stable diastereomers and enantiomers is detrimental for the potential bioactivity.

At this point, conscious of the intrinsic drawbacks due to the conformational and stereochemical dispersion of the synthesized cyclic peptoids, we decided to perform a test on silkworm larvae in order to evaluate general insecticidal activity.

\subsection{Insecticidal Activity against Silkworm Larvae}

Bassianolide (1) was reported to exhibit acute lethal toxicity against silkworm larvae [14]. We tested insecticidal activity of 5, a structural congener of bassianolide and analogues 6-8. Each peptoid in dimethyl sulfoxide (DMSO) was injected into open vessels of 4th-instar larvae. The administration of 5-8 caused death of a few larvae at a dose of $300 \mathrm{nmol} /$ larva after 72-120 
h (Table 2). Their toxicities were much weaker than that of bassianolide (1), which induced atonic symptom within $0.5 \mathrm{~h}$ and $100 \%$ mortality in a week at a dose of $5 \mu \mathrm{g}(=5.5 \mathrm{nmol}) /$ larva [14].

Table 2. Toxicity of 5-8 against silkworms by haemolymph injection a

\begin{tabular}{ccccccc}
\hline \multirow{2}{*}{ Compound } & \multicolumn{5}{c}{ Number of Dead Larvae $(n=\mathbf{1 0})$} \\
\cline { 2 - 7 } & $\mathbf{5}$ & $\mathbf{6}$ & $\mathbf{2 4}$ & $\mathbf{7 2}$ & $\mathbf{1 2 0}$ & $\mathbf{1 6 8}$ \\
\cline { 2 - 6 } & 0 & 0 & 0 & 0 & 0 & 0 \\
vehicle & 0 & 0 & 0 & 2 & 2 & 2 \\
$\mathbf{5}$ & 0 & 0 & 0 & 1 & 2 & 2 \\
$\mathbf{6}$ & 0 & 0 & 0 & 2 & 2 & 2 \\
$\mathbf{7}$ & 0 & 0 & 0 & 1 & 1 & 1 \\
$\mathbf{8}$ & &
\end{tabular}

a Each compound in DMSO was injected into 4th-instar larvae (ca $0.9 \mathrm{~g}$ body weight) at a dose of $300 \mathrm{nmol} /$ larva.

Anti-proliferative potentials of the $5-8$ were tested on A375 (human melanoma) cancer cell line. The cells were incubated for $72 \mathrm{~h}$ with increasing concentration of compounds (10-25-50 $\mu \mathrm{M})$ and cell viability was determined by MTT proliferation assay. The data indicated that the assayed compounds did not affect the cell vitality (see experimental part for general procedures).

\section{Experimental Section}

\subsection{Chemistry}

\subsubsection{General Methods}

Starting materials and reagents purchased from commercial suppliers were generally used without purification unless otherwise mentioned. HPLC analyses were performed on a JASCO LC-NET II/ADC equipped with a JASCO Model PU-2089 Plus Pump and a JASCO MD-2010 Plus UV-vis multiple wavelength detector set at $220 \mathrm{~nm}$. The column used was a $\mathrm{C}_{18}$ reversed-phase analytical column (Waters, Bondapak, $10 \mu \mathrm{m}, 125 \AA, 3.9 \mathrm{~mm} \times 300 \mathrm{~mm}$ ) run with linear gradients of ACN $\left(0.1 \%\right.$ TFA) into $\mathrm{H}_{2} \mathrm{O}(0.1 \%$ TFA) over $30 \mathrm{~min}$, at a flow rate of $1.0 \mathrm{~mL} / \mathrm{min}$ for the analytical runs. ESI-MS analysis in positive ion mode was performed using a Finnigan LCQ Deca ion trap mass spectrometer (ThermoFinnigan, San Josè, CA, USA) and the mass spectra were acquired and processed using the Xcalibur software provided by Thermo Finnigan. Samples were dissolved in 1:1 $\mathrm{CH}_{3} \mathrm{OH} / \mathrm{H}_{2} \mathrm{O}, 0.1 \%$ formic acid and infused in the ESI source by using a syringe pump; the flow rate was $5 \mu \mathrm{L} / \mathrm{min}$. The capillary voltage was set at $4.0 \mathrm{~V}$, the spray voltage at $5 \mathrm{kV}$ and the tube lens offset at $-40 \mathrm{~V}$. The capillary temperature was $220^{\circ} \mathrm{C}$. Data were acquired in MS1 and MSn scanning modes. Zoom scan was used in these experiments. High-resolution mass spectra (HRMS) were recorded on a Bruker Solarix XR Fourier transform ion cyclotron resonance mass spectrometer (FTICR-MS) equipped with a 7T magnet, using electrospray ionization (ESI). Yields refer to chromatographically and spectroscopically $\left({ }^{1} \mathrm{H}\right.$ - and ${ }^{13} \mathrm{C}$ NMR) pure materials. NMR spectra were recorded on a Bruker DRX $600\left({ }^{1} \mathrm{H}\right.$ at $600.13 \mathrm{MHz},{ }^{13} \mathrm{C}$ at $\left.150.90 \mathrm{MHz}\right)$, Bruker DRX $400\left({ }^{1} \mathrm{H}\right.$ at $400.13 \mathrm{MHz},{ }^{13} \mathrm{C}$ at $\left.100.03 \mathrm{MHz}\right)$, Bruker DRX $300\left({ }^{1} \mathrm{H}\right.$ at $300.13 \mathrm{MHz},{ }^{13} \mathrm{C}$ at $\left.75.03 \mathrm{MHz}\right)$. Chemical shifts $(\delta)$ are reported in ppm relative to the residual solvent peak $\left(\mathrm{CHCl}_{3}, \delta=7.26 ;{ }^{13} \mathrm{CDCl}_{3}, \delta=77.00 ; \mathrm{C}_{2} \mathrm{DHCl}_{4}, \mathrm{TCDE}, \delta=5.80\right)$ and the multiplicity of each signal is designated by the following abbreviations: s, singlet; $d$, doublet; $d d$, double doublet; $\mathrm{t}$, triplet; sept, septet; $\mathrm{m}$, multiplet; br, broad. 2D NMR experiments such as COSY, ROESY, HSQC and HMBC were performed for the full assignment of each signal. Coupling constants $(J)$ are quoted in Hertz. 


\subsubsection{General Procedure for the Solid-Phase Synthesis of Linear Peptoids 9-12}

The 2-chlorotrityl chloride resin ( $\alpha$-dichlorobenzhydryl-polystyrene cross-linked with $1 \%$ DVB; 100-200 mesh; $1.63 \mathrm{mmol} \mathrm{g}{ }^{-1}, 0.400 \mathrm{~g}, 0.652 \mathrm{mmol}$ ) was swelled in dry $\mathrm{CH}_{2} \mathrm{Cl}_{2}$ (4 mL) for $45 \mathrm{~min}$ and washed twice with dry $\mathrm{CH}_{2} \mathrm{Cl}_{2}(4 \mathrm{~mL})$. The first submonomer was attached onto the resin by adding bromoacetic acid $(0.136 \mathrm{~g}, 0.978 \mathrm{mmol})$ in dry $\mathrm{CH}_{2} \mathrm{Cl}_{2}(4 \mathrm{~mL})$ and DIPEA $(567 \mu \mathrm{L}, 3.26 \mathrm{mmol})$ on a shaker platform for $60 \mathrm{~min}$ at room temperature, followed by washing with $\mathrm{CH}_{2} \mathrm{Cl}_{2}(3 \times 1 \mathrm{~min})$ and then again with $\mathrm{DMF}(3 \times 1 \mathrm{~min})$. A solution of the chosen amine $(1.6 \mathrm{M}$ in dry $\mathrm{DMF}, 4 \mathrm{~mL}) \mathrm{was}$ added to the bromoacetylated resin. The mixture was left on a shaker platform for $40 \mathrm{~min}$ at room temperature, then the resin was washed with $\mathrm{DMF}(3 \times 1 \mathrm{~min}), \mathrm{CH}_{2} \mathrm{Cl}_{2}(3 \times 1 \mathrm{~min})$ and then again with DMF $(3 \times 1 \mathrm{~min})$. Subsequent bromoacetylation reactions were accomplished by reacting the aminated oligomer with a solution of bromoacetic acid $(0.910 \mathrm{~g}, 6.52 \mathrm{mmol})$ and DIC (1.11 mL, $7.17 \mathrm{mmol})$ in dry DMF ( $4 \mathrm{~mL}$ ) for $60 \mathrm{~min}$ at room temperature. The completion of the acylation reactions was verified by using the chloranil test. The filtrated resin was washed with $\mathrm{DMF}(3 \times 1 \mathrm{~min}), \mathrm{CH}_{2} \mathrm{Cl}_{2}(3 \times 1 \mathrm{~min})$, DMF $(3 \times 1 \mathrm{~min})$ and treated again with the proper amine under the same conditions reported above. This cycle of reactions was iterated until the target linear oligomer was obtained. The cleavage was performed treating the resin, previously washed with $\mathrm{CH}_{2} \mathrm{Cl}_{2}(3 \times 1 \mathrm{~min})$, three times with a solution of HFIP in $\mathrm{CH}_{2} \mathrm{Cl}_{2}(20 \% \mathrm{v} / \mathrm{v}, 4.0 \mathrm{~mL}$ each time) on a shaker platform at room temperature for $30 \mathrm{~min}$ each time. The resin was then filtered away and the combined filtrates were concentrated in vacuo. $1 \mathrm{mg}$ of the final products were dissolved in $60 \mu \mathrm{L}$ of acetonitrile $(0.1 \%$ TFA) and $60 \mu \mathrm{L}$ of HPLC grade water ( $0.1 \%$ TFA) and analysed by RP-HPLC; purity $\geq 71 \%$; conditions: $5 \rightarrow 100 \%$ A in 30 min for the all oligomers (A, 0.1\% TFA in acetonitrile, B, 0.1\% TFA in water); flow: $1.0 \mathrm{~mL} \mathrm{~min} \mathrm{~m}^{-1}, 220 \mathrm{~nm}$ ]. The linear oligomers (isolated as amorphous solids) were subjected to ESI mass spectrometry (see Table 1) and, subsequently, to the cyclization reactions without further purification.

\subsubsection{General Procedure for the High Dilution Cyclization. Synthesis of Cyclic Peptoids 5-8}

The solutions of the linear peptoids $(0.150 \mathrm{mmol})$, previously co-evaporated three times with toluene, were prepared under nitrogen in dry DCM $(5.0 \mathrm{~mL})$. The mixture was added dropwise to a stirred solution of HATU $(0.171 \mathrm{~g}, 0.450 \mathrm{mmol})$ and DIPEA $(104 \mu \mathrm{L}, 0.600 \mathrm{mmol})$ in dry DMF $(45.0 \mathrm{~mL})$ by a syringe pump in $5 \mathrm{~h}$, at room temperature in anhydrous atmosphere. After $12 \mathrm{~h}$ the resulting mixture was concentrated in vacuo, diluted with $\mathrm{CH}_{2} \mathrm{Cl}_{2}(30 \mathrm{~mL})$ and washed with a solution of $\mathrm{HCl}$ $(1.0 \mathrm{M}, 15 \mathrm{~mL})$. The aqueous phase was then extracted again with $30 \mathrm{~mL}$ of $\mathrm{CH}_{2} \mathrm{Cl}_{2}$. The organic phases were washed with water $(60.0 \mathrm{~mL})$, dried over anhydrous $\mathrm{MgSO}_{4}$, filtered and concentrated in vacuo. The cyclic peptoids were dissolved in 50\% acetonitrile in HPLC grade water and analysed by RP-HPLC; purity > 90\% conditions: $5-100 \% \mathrm{~A}$ in $30 \mathrm{~min}$ (A, 0.1\% TFA in acetonitrile, B, 0.1\% TFA in water); flow: $1 \mathrm{~mL} \mathrm{~min}-1,220 \mathrm{~nm}$. The crude cyclic peptoids 5, 7 were dissolved in hot acetonitrile and precipitated by slowly cooling the acetonitrile solutions. The crude 6, 8 were purified on reverse silica gel $\left(\mathrm{C}_{18}\right)$; conditions: $10-100 \% \mathrm{~A}$ (A: acetonitrile; $\mathrm{B}$ : water).

5: white amorphous solid, $0.027 \mathrm{~g}$, yield: $21 \%$; $t_{R}: 12.1 \mathrm{~min} .{ }^{1} \mathrm{H}-\mathrm{NMR}\left(400 \mathrm{MHz}, \mathrm{CDCl}_{3}, c\right.$ stands for cis amide bond, $t$ stands for trans amide bond) $\delta: 4.77\left(2 \mathrm{H}, \mathrm{m}, \mathrm{N}-\mathrm{CH}\left(\mathrm{CH}_{3}\right)_{2}, c\right), 4.74(2 \mathrm{H}, \mathrm{d}, J 16.1 \mathrm{~Hz}$, $\mathrm{O}=\mathrm{C}-\mathrm{CHH}-\mathrm{N}-i \mathrm{Bu}, t), 4.32(2 \mathrm{H}, \mathrm{d}, J 17.8 \mathrm{~Hz}, \mathrm{O}=\mathrm{C}-\mathrm{CHH}-\mathrm{N}-i \mathrm{Bu}, c), 4.23(2 \mathrm{H}, \mathrm{d}, J 17.7 \mathrm{~Hz}, \mathrm{O}=\mathrm{C}-\mathrm{CHH}-\mathrm{N}-i \mathrm{Pr}$, t), $4.13(2 \mathrm{H}, \mathrm{d}, J 17.8 \mathrm{~Hz}, \mathrm{O}=\mathrm{C}-\mathrm{CHH}-\mathrm{N}-\mathrm{Pr}, c), 3.96(2 \mathrm{H}, \mathrm{d}, J 17.8 \mathrm{~Hz}, \mathrm{O}=\mathrm{C}-\mathrm{CH} H-\mathrm{N}-\mathrm{Pr}, c), 3.87$ (m, $2 \mathrm{H}$, $\left.\mathrm{N}-\mathrm{CH}\left(\mathrm{CH}_{3}\right)_{2}, t\right), 3.64\left(2 \mathrm{H}, \mathrm{dd}, J\right.$ 14.1, $\left.7.4 \mathrm{~Hz}, \mathrm{~N}-\mathrm{CHH}-\mathrm{CH}\left(\mathrm{CH}_{3}\right)_{2}, c\right), 3.60(4 \mathrm{H}, \mathrm{d}, \mathrm{O}=\mathrm{C}-\mathrm{CH} H-\mathrm{N}-i \mathrm{Bu}$, $t$ and $\mathrm{O}=\mathrm{C}-\mathrm{CH} H-\mathrm{N}-i \mathrm{Bu}, c$, overlapping), $3.51(2 \mathrm{H}, \mathrm{d}, J 17.7 \mathrm{~Hz}, \mathrm{O}=\mathrm{C}-\mathrm{CH} H-\mathrm{N}-i \mathrm{Pr}, t), 3.22(2 \mathrm{H}, \mathrm{dd}$, $J$ 13.9, $\left.5.0 \mathrm{~Hz}, \mathrm{~N}-\mathrm{CHH}-\mathrm{CH}\left(\mathrm{CH}_{3}\right)_{2}, t\right), 3.09\left(2 \mathrm{H}, \mathrm{dd}, J\right.$ 13.9, $\left.5.0 \mathrm{~Hz}, \mathrm{~N}-\mathrm{CH}-\mathrm{CH}\left(\mathrm{CH}_{3}\right)_{2}, t\right), 2.68(2 \mathrm{H}, \mathrm{dd}$, $J$ 14.1, 7.4 Hz, N-CHH-CH$\left.\left(\mathrm{CH}_{3}\right)_{2}, c\right), 1.87\left(4 \mathrm{H}, \mathrm{m}, \mathrm{N}-\mathrm{CH}_{2}-\mathrm{CH}\left(\mathrm{CH}_{3}\right)_{2}, c\right.$ and $\left.t\right), 1.21(6 \mathrm{H}, \mathrm{d}, J 6.7 \mathrm{~Hz}$, $\left.\mathrm{N}-\mathrm{CH}\left(\mathrm{CH}_{3}\right)_{2}, t\right), 1.14\left(6 \mathrm{H}, \mathrm{d}, J 6.7 \mathrm{~Hz}, \mathrm{~N}-\mathrm{CH}\left(\mathrm{CH}_{3}\right)_{2}, c\right), 1.11\left(6 \mathrm{H}, \mathrm{d}, J 6.7 \mathrm{~Hz}, \mathrm{~N}-\mathrm{CH}\left(\mathrm{CH}_{3}\right)_{2}, t\right), 1.05(6 \mathrm{H}$, $\left.\mathrm{d}, J 6.7 \mathrm{~Hz}, \mathrm{~N}-\mathrm{CH}\left(\mathrm{CH}_{3}\right)_{2}, c\right), 0.98\left(12 \mathrm{H}, \mathrm{d}, J 6.5 \mathrm{~Hz}, \mathrm{~N}-\mathrm{CH}_{2}-\mathrm{CH}\left(\mathrm{CH}_{3}\right)_{2}, c\right.$ and $\left.t\right), 0.91(6 \mathrm{H}, \mathrm{d}, J 6.5 \mathrm{~Hz}$, $\left.\mathrm{N}-\mathrm{CH}_{2}-\mathrm{CH}\left(\mathrm{CH}_{3}\right)_{2}, t\right), 0.82\left(6 \mathrm{H}, \mathrm{d}, J 6.5 \mathrm{~Hz}, \mathrm{~N}-\mathrm{CH}_{2}-\mathrm{CH}\left(\mathrm{CH}_{3}\right)_{2}, c\right) .{ }^{13} \mathrm{C}-\mathrm{NMR}\left(100 \mathrm{MHz}, \mathrm{CDCl}_{3}\right) \delta: 170.3$ (x2), $169.4(x 2), 169.3(x 2), 166.1(x 2), 56.2(x 2), 55.8(x 2), 50.6(x 2), 49.0(x 2), 48.0(x 2), 45.6(x 2), 43.2(x 2)$, 
42.8 (x2), 27.8 (x2), 27.0 (x2), 20.9 (x2), 20.6 (x3), 20.4 (x3), 19.9 (x4), 19.6 (x2), 19.6 (x2). HR-ESI-MS m/z: $849.6170[\mathrm{M}+\mathrm{H}]^{+}$(calcd. for $\left.\mathrm{C}_{44} \mathrm{H}_{81} \mathrm{~N}_{8} \mathrm{O}_{8}{ }^{+}, 849.6172\right)$.

6: white amorphous solid, $0.041 \mathrm{~g}$, yield: $31 \%$; $t_{R}$ : $12.6 \mathrm{~min} .{ }^{1} \mathrm{H}-\mathrm{NMR}\left(400 \mathrm{MHz}, \mathrm{CDCl}_{3}, c\right.$ stands for cis amide bond, $t$ stands for trans amide bond) $\delta:$ 7.36-7.34-7.23 $(10 \mathrm{H}$, overlapping, Ar- $H), 5.52(1 \mathrm{H}, \mathrm{d}$, $J 15.6 \mathrm{~Hz}, \mathrm{~N}-\mathrm{CHH}-\mathrm{Ph}, c), 5.39(1 \mathrm{H}, \mathrm{d}, J 14.5 \mathrm{~Hz}, \mathrm{~N}-\mathrm{CHH}-\mathrm{Ph}, c), 4.91\left(1 \mathrm{H}, \mathrm{d}, J 16.8 \mathrm{~Hz}, \mathrm{O}=\mathrm{C}-\mathrm{CHH}-\mathrm{N}-\mathrm{CH}_{3}\right.$, t), $4.84\left(1 \mathrm{H}, \mathrm{d}, J 17.0 \mathrm{~Hz}, \mathrm{O}=\mathrm{C}-\mathrm{CHH}-\mathrm{N}-\mathrm{CH}_{3}, t\right), 4.71(1 \mathrm{H}, \mathrm{d}, J 17.8 \mathrm{~Hz}, \mathrm{O}=\mathrm{C}-\mathrm{CHH}-\mathrm{N}-i \mathrm{Bu}, t)$, $4.67(1 \mathrm{H}, \mathrm{d}, J 16.0 \mathrm{~Hz}, \mathrm{O}=\mathrm{C}-\mathrm{CHH}-\mathrm{N}-i \mathrm{Bu}, t), 4.37(1 \mathrm{H}, \mathrm{d}, J 16.8 \mathrm{~Hz}, \mathrm{O}=\mathrm{C}-\mathrm{CHH}-\mathrm{N}-i \mathrm{Bu}, c), 4.22$ $(1 \mathrm{H}, \mathrm{d}, J 17.9 \mathrm{~Hz}, \mathrm{O}=\mathrm{C}-\mathrm{CHH}-\mathrm{N}-\mathrm{Bn}, c), 4.14(1 \mathrm{H}, \mathrm{d}, J 15.6 \mathrm{~Hz}, \mathrm{O}=\mathrm{C}-\mathrm{CHH}-\mathrm{N}-\mathrm{Bn}, c), 4.09(1 \mathrm{H}, \mathrm{d}$, $J 18.3 \mathrm{~Hz}, \mathrm{O}=\mathrm{C}-\mathrm{CH} H-\mathrm{N}-i \mathrm{Bu}, c), 4.03(1 \mathrm{H}, \mathrm{d}, J 14.5 \mathrm{~Hz}, \mathrm{~N}-\mathrm{CH} H-\mathrm{Ph}, c), 3.92(1 \mathrm{H}, \mathrm{dd}, J$ 13.5, 7.2 Hz, $\left.\mathrm{N}-\mathrm{CHH}-\mathrm{CH}\left(\mathrm{CH}_{3}\right)_{2}, c\right), 3.79(1 \mathrm{H}, \mathrm{d}, J 18.5 \mathrm{~Hz}, \mathrm{O}=\mathrm{C}-\mathrm{CHH}-\mathrm{N}-\mathrm{BBu}, c), 3.77(2 \mathrm{H}, \mathrm{d}, J 15.6 \mathrm{~Hz}, \mathrm{~N}-\mathrm{CHH}-\mathrm{Ph}$, $c$ and $\mathrm{O}=\mathrm{C}-\mathrm{CHH}-\mathrm{N}-\mathrm{Bn}, \mathrm{c}$, overlapping), $3.75\left(1 \mathrm{H}, \mathrm{m}\right.$, overlapping signals, $\left.\mathrm{N}-\mathrm{CHH}-\mathrm{CH}\left(\mathrm{CH}_{3}\right)_{2}, c\right)$, $3.71(1 \mathrm{H}, \mathrm{d}, J 16.8 \mathrm{~Hz}, \mathrm{O}=\mathrm{C}-\mathrm{CH} H-\mathrm{N}-i \mathrm{Bu}, c), 3.52(1 \mathrm{H}, \mathrm{d}, J 16.0 \mathrm{~Hz}, \mathrm{O}=\mathrm{C}-\mathrm{CH} H-\mathrm{N}-i \mathrm{Bu}, t), 3.51(1 \mathrm{H}, \mathrm{d}$, $J$ 17.0 Hz, O=C-CHH-N-CH$\left.{ }_{3}, t\right), 3.48(1 \mathrm{H}, \mathrm{d}, J 17.9 \mathrm{~Hz}, \mathrm{O}=\mathrm{C}-\mathrm{CH} H-\mathrm{N}-\mathrm{Bn}, c), 3.30(1 \mathrm{H}, \mathrm{d}, J 17.8 \mathrm{~Hz}$, $\mathrm{O}=\mathrm{C}-\mathrm{CHH}-\mathrm{N}-\mathrm{BBu}, t), 3.10\left(1 \mathrm{H}, \mathrm{d}, J 16.8 \mathrm{~Hz}, \mathrm{O}=\mathrm{C}-\mathrm{CHH}-\mathrm{N}-\mathrm{CH}_{3}, t\right), 3.05(1 \mathrm{H}, \mathrm{dd}, J$ 13.2, $6.5 \mathrm{~Hz}$, $\left.\mathrm{N}-\mathrm{CHH}-\mathrm{CH}\left(\mathrm{CH}_{3}\right)_{2}, t\right), 3.00\left(3 \mathrm{H}, \mathrm{s}, \mathrm{N}-\mathrm{CH}_{3}, t\right), 2.99\left(2 \mathrm{H}, \mathrm{m}\right.$, overlapping signals, $\left.\mathrm{N}-\mathrm{CH}_{2}-\mathrm{CH}\left(\mathrm{CH}_{3}\right)_{2}, t\right)$, $2.97\left(3 \mathrm{H}, \mathrm{s}, \mathrm{N}-\mathrm{CH}_{3}, t\right), 2.96\left(1 \mathrm{H}, \mathrm{dd}, J\right.$ 13.2, $\left.6.5 \mathrm{~Hz}, \mathrm{~N}-\mathrm{CH} H-\mathrm{CH}\left(\mathrm{CH}_{3}\right)_{2}, t\right), 2.87(1 \mathrm{H}, \mathrm{dd}, J$ 14.0, $7.6 \mathrm{~Hz}$, $\left.\mathrm{N}-\mathrm{CHH}-\mathrm{CH}\left(\mathrm{CH}_{3}\right)_{2}, c\right), 2.44\left(1 \mathrm{H}, \mathrm{dd}, J 13.5,7.2 \mathrm{~Hz}, \mathrm{~N}-\mathrm{CHH}-\mathrm{CH}\left(\mathrm{CH}_{3}\right)_{2}, c\right), 1.97-1.72(4 \mathrm{H}, \mathrm{m}$, overlapping signals, $\mathrm{N}-\mathrm{CH}_{2}-\mathrm{CH}\left(\mathrm{CH}_{3}\right)_{2}, c$ and $\left.t\right), 0.97-0.77\left(24 \mathrm{H}\right.$, overlapping signals, $\mathrm{N}-\mathrm{CH}_{2}-\mathrm{CH}\left(\mathrm{CH}_{3}\right)_{2}, c$ and $\left.t\right)$. ${ }^{13} \mathrm{C}-\mathrm{NMR}\left(150 \mathrm{MHz}, \mathrm{CDCl}_{3}\right)$ ): 170.2, 169.8, 169.6, 169.3 (x2), 168.5, 167.2, 166.7, 136.6 (x2), 129.2, 129.0 (x3), 128.8 (x2), 128.6, 127.8, 127.4, 127.0, 56.1 (x2), 55.8, 55.1, 52.0, 50.9, 50.8, 50.4, 50.1, 49.8, 49.5, 49.2, 48.0, 46.9, 36.8, 35.4, 29.7, 27.8, 27.2 (x2), 20.6 (x2), 20.5, 20.3 (x2), 20.0, 19.9, 19.7. HR-ESI-MS $\mathrm{m} / \mathrm{z}$ : $889.5543[\mathrm{M}+\mathrm{H}]^{+}$(calcd. for $\mathrm{C}_{48} \mathrm{H}_{73} \mathrm{~N}_{8} \mathrm{O}_{8}{ }^{+}$, 889.5546).

7: white amorphous solid, $0.045 \mathrm{~g}$, yield: $29 \%$; $t_{R}$ : $14.6 \mathrm{~min} .{ }^{1} \mathrm{H}-\mathrm{NMR}\left(400 \mathrm{MHz}, \mathrm{CDCl}_{3}, c\right.$ stands for cis amide bond, $t$ stands for trans amide bond) $\delta: 7.36-7.18(20 \mathrm{H}$, overlapping, Ar- $H), 5.40(2 \mathrm{H}, \mathrm{d}, J 15.0 \mathrm{~Hz}$, N-CHH-Ph, c), $4.83(2 \mathrm{H}, \mathrm{d}, J 17.3 \mathrm{~Hz}, \mathrm{O}=\mathrm{C}-\mathrm{CHH}-\mathrm{N}-i \mathrm{Bu}, t), 4.77(2 \mathrm{H}, \mathrm{d}, J 16.1 \mathrm{~Hz}, \mathrm{O}=\mathrm{C}-\mathrm{CHH}-\mathrm{N}-\mathrm{Bn}$, t), $4.71(2 \mathrm{H}, \mathrm{d}, J 16.6 \mathrm{~Hz}, \mathrm{~N}-\mathrm{CHH}-\mathrm{Ph}, t), 4.32(2 \mathrm{H}, \mathrm{d}, J 17.8 \mathrm{~Hz}, \mathrm{~N}-\mathrm{CHH}-\mathrm{Ph}, t), 4.27(4 \mathrm{H}, \mathrm{d}, J 19.0 \mathrm{~Hz}$, $\mathrm{O}=\mathrm{C}-\mathrm{CHH}-\mathrm{N}-\mathrm{Bn}, c$ and $\mathrm{O}=\mathrm{C}-\mathrm{CHH}-\mathrm{N}-\mathrm{iBu}, c$, overlapping), $3.98(2 \mathrm{H}, \mathrm{d}, J 15.0 \mathrm{~Hz}, \mathrm{~N}-\mathrm{CH} H-\mathrm{Ph}, c)$, $3.85\left(2 \mathrm{H}, \mathrm{dd}, J\right.$ 13.6, $\left.7.2 \mathrm{~Hz}, \mathrm{~N}-\mathrm{CHH}-\mathrm{CH}\left(\mathrm{CH}_{3}\right)_{2}, c\right), 3.71(2 \mathrm{H}, \mathrm{d}, J 19.0 \mathrm{~Hz}, \mathrm{O}=\mathrm{C}-\mathrm{CH} H-\mathrm{N}-\mathrm{B} \mathrm{Bu}, c)$, $3.61(2 \mathrm{H}, \mathrm{d}, J 16.1 \mathrm{~Hz}, \mathrm{O}=\mathrm{C}-\mathrm{CH} H-\mathrm{N}-\mathrm{Bn}, t), 3.53(2 \mathrm{H}, \mathrm{d}, J 19.0 \mathrm{~Hz}, \mathrm{O}=\mathrm{C}-\mathrm{CH} H-\mathrm{N}-\mathrm{Bn}, c), 3.38(2 \mathrm{H}$, d, J $17.3 \mathrm{~Hz}, \mathrm{O}=\mathrm{C}-\mathrm{CH} H-\mathrm{N}-i \mathrm{Bu}, t), 3.03\left(2 \mathrm{H}, \mathrm{dd}, J\right.$ 14.9, $\left.7.6 \mathrm{~Hz}, \mathrm{~N}-\mathrm{CHH}-\mathrm{CH}\left(\mathrm{CH}_{3}\right)_{2}, t\right), 2.83(2 \mathrm{H}, \mathrm{dd}$, $J$ 14.9, 7.6 Hz, N-CHH-CH$\left.\left(\mathrm{CH}_{3}\right)_{2}, t\right), 2.42\left(2 \mathrm{H}, \mathrm{dd}, J\right.$ 13.6, $\left.7.2 \mathrm{~Hz}, \mathrm{~N}-\mathrm{CHH}-\mathrm{CH}\left(\mathrm{CH}_{3}\right)_{2}, c\right), 1.97(2 \mathrm{H}, \mathrm{m}$, $\left.\mathrm{N}-\mathrm{CH}_{2}-\mathrm{CH}\left(\mathrm{CH}_{3}\right)_{2}, t\right), 1.68\left(2 \mathrm{H}, \mathrm{m}, \mathrm{N}-\mathrm{CH}_{2}-\mathrm{CH}\left(\mathrm{CH}_{3}\right)_{2}, c\right), 0.92\left(12 \mathrm{H}, \mathrm{t}, J 7.3 \mathrm{~Hz}, \mathrm{~N}-\mathrm{CH}_{2}-\mathrm{CH}\left(\mathrm{CH}_{3}\right)_{2}, t\right.$, overlapping signals), $0.82\left(6 \mathrm{H}, \mathrm{d}, J 6.5 \mathrm{~Hz}, \mathrm{~N}-\mathrm{CH}_{2}-\mathrm{CH}\left(\mathrm{CH}_{3}\right)_{2}, c\right), 0.77\left(6 \mathrm{H}, \mathrm{d}, J 6.5 \mathrm{~Hz}, \mathrm{~N}-\mathrm{CH}_{2}-\mathrm{CH}\left(\mathrm{CH}_{3}\right)_{2}\right.$, c). ${ }^{13} \mathrm{C}-\mathrm{NMR}\left(100 \mathrm{MHz}, \mathrm{CDCl}_{3}\right)$ 8: 169.8 (x2), 169.7 (x2), 169.3 (x2), $167.4(\mathrm{x} 2), 136.6(\mathrm{x} 2), 135.9$ (x2), $129.1(x 4), 128.8(x 4), 128.6(x 4), 128.0(x 2), 127.3(x 2), 126.7(x 4), 55.8(x 2), 55.1(x 2), 52.3(x 2), 50.1(x 2)$, 49.7 (x2), 49.4 (x2), 48.0 (x2), 47.1 (x2), 27.2 (x2), 20.4 (x2), 20.3 (x2), 20.2 (x2), 19.9 (x4). HR-ESI-MS m/z: $1041.6171[\mathrm{M}+\mathrm{H}]^{+}$(calcd. for $\left.\mathrm{C}_{60} \mathrm{H}_{81} \mathrm{~N}_{8} \mathrm{O}_{8}{ }^{+}, 1041.6172\right)$.

8: white amorphous solid, $0.040 \mathrm{~g}$, yield: $34 \%$; $t_{R}$ : $13.3 \mathrm{~min} .{ }^{1} \mathrm{H}-\mathrm{NMR}\left(400 \mathrm{MHz}, \mathrm{CDCl}_{3}\right.$, mixture of rotamers) $\delta$ : 4.84-2.94 (36H, overlapping signals, $\mathrm{O}=\mathrm{C}-\mathrm{CH}_{2}-\mathrm{N}-\mathrm{CH}_{3}, \mathrm{O}=\mathrm{C}-\mathrm{CH}_{2}-\mathrm{N}-\mathrm{CH}_{2} \mathrm{CH}_{2} \mathrm{CH}_{2} \mathrm{CH}_{2} \mathrm{CH}_{3}$, $\left.\mathrm{N}-\mathrm{CH}_{2} \mathrm{CH}_{2} \mathrm{CH}_{2} \mathrm{CH}_{2} \mathrm{CH}_{3}, \mathrm{O}=\mathrm{C}-\mathrm{CH}_{2}-\mathrm{N}-\mathrm{CH}_{3}\right), 1.58-1.44\left(8 \mathrm{H}\right.$, br signals, overlapping, $\mathrm{N}-\mathrm{CH}_{2} \mathrm{CH}_{2} \mathrm{CH}_{2}$ $\left.\mathrm{CH}_{2} \mathrm{CH}_{3}\right), 1.33-1.22\left(16 \mathrm{H}\right.$, overlapping signals, $\left.\mathrm{N}-\mathrm{CH}_{2} \mathrm{CH}_{2} \mathrm{CH}_{2} \mathrm{CH}_{2} \mathrm{CH}_{3}\right), 0.92-0.83(12 \mathrm{H}$, overlapping signals, $\left.\mathrm{N}-\mathrm{CH}_{2} \mathrm{CH}_{2} \mathrm{CH}_{2} \mathrm{CH}_{2} \mathrm{CH}_{3}\right) ;{ }^{13} \mathrm{C}-\mathrm{NMR}\left(100 \mathrm{MHz}, \mathrm{CDCl}_{3}\right) \delta: 169.9,169.3,169.2,169.0,168.0$, 167.0, 51.6, 50.8, 50.5, 50.3, 49.0, 48.9, 48.6, 48.4, 48.0, 47.7, 36.6, 35.9, 35.5, 29.1, 29.0, 28.9, 28.7, 28.5, 27.5, 27.3, 27.0, 22.4, 22.2, 14.0. HR-ESI-MS $m / z: 793.5540[\mathrm{M}+\mathrm{H}]^{+}$(calcd. for $\mathrm{C}_{40} \mathrm{H}_{73} \mathrm{~N}_{8} \mathrm{O}_{8}{ }^{+}$, 793.5546).

\subsubsection{General Procedure for the $\mathrm{Na}^{+}$Complexes Formation $[5-8 \cdot 2 \mathrm{Na}]^{2+} \cdot 2[\mathrm{TFPB}]^{2-}$}

To a solution of cyclic peptoids $5-8$ in $\mathrm{CDCl}_{3}(0.9 \mathrm{~mL}) 2.0$ equivalents of NaTFPB (previously dissolved in $\mathrm{CD}_{3} \mathrm{CN}, 0.1 \mathrm{~mL}$ ) were added. After the addition, the mixtures were sonicated for $5 \mathrm{~min}$ in a heated bath $\left(25^{\circ} \mathrm{C}\right)$. The $\mathrm{H} \cdot \mathrm{G}_{2}$ solutions were concentrated under a nitrogen flux and dried under 
vacuum. The complexes were then dissolved in $\mathrm{CDCl}_{3}(1.0 \mathrm{~mL})$ with the help of the sonicator (5 to $10 \mathrm{~min})$. The $\mathrm{H} \cdot \mathrm{G}_{2}$ complex concentration, at the equilibrium-[H.G $\left.]_{2}\right]_{\text {eq }}$-was evaluated by integration of the ${ }^{1} \mathrm{H}$ NMR complex signals (2.5-6.0 range) versus the total integration of the free host plus complexed molecules at $298 \mathrm{~K}$. With the addition of 2 equivalents of guest, the equilibrium (1) is established:

$$
\begin{gathered}
\mathrm{H}+2 \mathrm{G} \rightleftarrows \mathrm{H} \cdot \mathrm{G}_{2} \\
{[\mathrm{H}]_{\mathrm{eq}}=[\mathrm{H}]_{\mathrm{i}}-\left[\mathrm{H} \cdot \mathrm{G}_{2}\right]_{\mathrm{eq}}} \\
{[\mathrm{G}]_{\mathrm{eq}}=[\mathrm{G}]_{\mathrm{i}}-2\left[\mathrm{H} \cdot \mathrm{G}_{2}\right]_{\mathrm{eq}}}
\end{gathered}
$$

where $[\mathrm{G}]_{\mathrm{i}}=2[\mathrm{H}]_{\mathrm{i}}$. The $K_{\mathrm{aTOT}}\left(=K_{\mathrm{a} 1} \cdot K_{\mathrm{a} 2}\right.$, where $K_{\mathrm{a} 1}$ is the equilibrium constant associated with the formation of the monometallic complex, $K_{\mathrm{a} 2}$ is the equilibrium constant associated with the formation of the bimetallic complex, starting from the monometallic one), was calculated as follows:

$$
K_{\mathrm{a}}=\frac{[\mathrm{H} \cdot \mathrm{G}]_{\mathrm{eq}}}{[\mathrm{H}]_{\mathrm{eq}} \times[\mathrm{G}]_{\mathrm{eq}}^{2}}
$$

for the equilibrium (1).

In order to have the reliable integration values, the delay times (D1) among successive scans, in the ${ }^{1} \mathrm{H}$ NMR, were set at $5 \mathrm{~s}$.

[5.2Na $]^{2+}$ 2TFPB ${ }^{-}$: white amorphous solid. ${ }^{1} \mathrm{H}$ NMR $\left(400 \mathrm{MHz}, \mathrm{CDCl}_{3}\right)$ 8: $7.68(16 \mathrm{H}, \mathrm{s}, \mathrm{TFPB}-\mathrm{o}-\mathrm{H}), 7.52$ $(8 \mathrm{H}, \mathrm{s}, \mathrm{TFPB}-\mathrm{p}-\mathrm{H}), 4.82(4 \mathrm{H}, \mathrm{d}, J 16.5 \mathrm{~Hz}, \mathrm{O}=\mathrm{C}-\mathrm{CHH}-\mathrm{N}-i \mathrm{Bu}), 4.59(4 \mathrm{H}, \mathrm{d}, J 16.6 \mathrm{~Hz}, \mathrm{O}=\mathrm{C}-\mathrm{CHH}-\mathrm{N}-\mathrm{PPr})$, $3.96\left(4 \mathrm{H}\right.$, ept, J $\left.6.8 \mathrm{~Hz},-\mathrm{CH}\left(\mathrm{CH}_{3}\right)_{2}\right), 3.72(4 \mathrm{H}, \mathrm{d}, J 16.6 \mathrm{~Hz}, \mathrm{O}=\mathrm{C}-\mathrm{CHH}-\mathrm{N}-\mathrm{Pr}), 3.63(4 \mathrm{H}, \mathrm{d}, J 16.5 \mathrm{~Hz}$, $\mathrm{O}=\mathrm{C}-\mathrm{CHH}-\mathrm{N}-\mathrm{iBu}), 3.14\left(4 \mathrm{H}, \mathrm{dd}, J\right.$ 14.7, $\left.7.2 \mathrm{~Hz}, \mathrm{~N}-\mathrm{CHH}-\mathrm{CH}\left(\mathrm{CH}_{3}\right)_{2}\right), 2.92(4 \mathrm{H}, \mathrm{dd}, J$ 14.7, $7.2 \mathrm{~Hz}$, $\left.\mathrm{N}-\mathrm{CH}-\mathrm{CH}\left(\mathrm{CH}_{3}\right)_{2}\right), 1.83\left(4 \mathrm{H}, \mathrm{m}, \mathrm{N}-\mathrm{CH}_{2}-\mathrm{CH}\left(\mathrm{CH}_{3}\right)_{2}\right), 1.18\left(12 \mathrm{H}, \mathrm{d}, J 5.6 \mathrm{~Hz}, \mathrm{~N}-\mathrm{CH}\left(\mathrm{CH}_{3}\right)\left(\mathrm{CH}_{3}\right)\right), 1.03$ $\left(12 \mathrm{H}, \mathrm{d}, J 5.6 \mathrm{~Hz}, \mathrm{~N}-\mathrm{CH}\left(\mathrm{CH}_{3}\right)\left(\mathrm{CH}_{3}\right)\right), 0.95\left(24 \mathrm{H}, \mathrm{d}, J 5.3 \mathrm{~Hz}, \mathrm{~N}-\mathrm{CH}_{2}-\mathrm{CH}\left(\mathrm{CH}_{3}\right)_{2}\right) ;{ }^{13} \mathrm{C}-\mathrm{NMR}(100 \mathrm{MHz}$, $\mathrm{CDCl}_{3}$, the TFPB numbering is reported in the S.I.) $\delta: 170.0(\mathrm{x} 4), 168.1(\mathrm{x} 4), 161.7(\mathrm{q}, J 50 \mathrm{~Hz}, \mathrm{C}-1), 136.2$, 134.8, (C-2), 128.8 (q, J $30 \mathrm{~Hz}, \mathrm{C}-3), 124.6$ (q, J $270 \mathrm{~Hz}, \mathrm{C}-5), 117.4$ (C-4), 56.1 (x6), 48.4 (x2), 48.1 (x4), 42.2 (x4), $27.3(\mathrm{x} 4), 20.9(\mathrm{x} 4), 19.9(\mathrm{x} 12)$.

[6.2Na $]^{2+}$ 2TFPB': white amorphous solid. ${ }^{1} \mathrm{H}$ NMR $\left(400 \mathrm{MHz}, \mathrm{CDCl}_{3}\right)$ 8: $7.69(16 \mathrm{H}, \mathrm{s}, \mathrm{TFPB}-o-H), 7.52$ $(8 \mathrm{H}, \mathrm{s}$, TFPB-p- $H)$, 7.43-7.41 (6H, overlapping, Ar- $H), 7.13(4 \mathrm{H}, \mathrm{d}, J 6.9 \mathrm{~Hz}, \mathrm{Ar}-\mathrm{H}), 4.97(2 \mathrm{H}, \mathrm{d}, J 17.0 \mathrm{~Hz}$, $\mathrm{O}=\mathrm{C}-\mathrm{CHH}-\mathrm{N}), 4.88\left(2 \mathrm{H}, \mathrm{d}, J 16.8 \mathrm{~Hz}, \mathrm{O}=\mathrm{C}-\mathrm{CHH}-\mathrm{N}-\mathrm{CH}_{3}\right), 4.86(2 \mathrm{H}, \mathrm{d}, J 16.7 \mathrm{~Hz}, \mathrm{O}=\mathrm{C}-\mathrm{CHH}-\mathrm{N}), 4.72$ $(2 \mathrm{H}, \mathrm{d}, J 16.7 \mathrm{~Hz}, \mathrm{O}=\mathrm{C}-\mathrm{CHH}-\mathrm{N}), 4.70\left(2 \mathrm{H}, \mathrm{d}, J 16.7 \mathrm{~Hz}, \mathrm{O}=\mathrm{C}-\mathrm{CH}_{2}-\mathrm{N}-\mathrm{CHH}-\mathrm{Ph}\right), 4.22(2 \mathrm{H}, \mathrm{d}, J 16.7 \mathrm{~Hz}$, $\left.\mathrm{O}=\mathrm{C}-\mathrm{CH}_{2}-\mathrm{N}-\mathrm{CHH}-\mathrm{Ph}\right), 3.66(2 \mathrm{H}, \mathrm{d}, J 17.0 \mathrm{~Hz}, \mathrm{O}=\mathrm{C}-\mathrm{CHH}-\mathrm{N}), 3.65(2 \mathrm{H}, \mathrm{d}, J 16.7 \mathrm{~Hz}, \mathrm{O}=\mathrm{C}-\mathrm{CHH}-\mathrm{N})$, $3.54\left(2 \mathrm{H}, \mathrm{d}, J 16.8 \mathrm{~Hz}, \mathrm{O}=\mathrm{C}-\mathrm{CH} H-\mathrm{N}-\mathrm{CH}_{3}\right), 3.53(2 \mathrm{H}, \mathrm{d}, J 16.7 \mathrm{~Hz}, \mathrm{O}=\mathrm{C}-\mathrm{CHH}-\mathrm{N}), 3.10(6 \mathrm{H}$, overlapping, $\left.\mathrm{N}-\mathrm{CH}_{2}-\mathrm{CH}\left(\mathrm{CH}_{3}\right)_{2}\right), 2.85\left(6 \mathrm{H}, \mathrm{s}, \mathrm{N}-\mathrm{CH}_{3}\right), 2.80\left(2 \mathrm{H}\right.$, overlapping, $\left.\mathrm{N}-\mathrm{CH}_{2}-\mathrm{CH}\left(\mathrm{CH}_{3}\right)_{2}\right), 2.01(4 \mathrm{H}, \mathrm{m}$, $\left.\mathrm{N}-\mathrm{CH}_{2}-\mathrm{CH}\left(\mathrm{CH}_{3}\right)_{2}\right), 0.85\left(24 \mathrm{H}, \mathrm{d}, J 6.3 \mathrm{~Hz}, \mathrm{~N}-\mathrm{CH}_{2}-\mathrm{CH}\left(\mathrm{CH}_{3}\right)_{2}\right) ;{ }^{13} \mathrm{C}-\mathrm{NMR}\left(150 \mathrm{MHz}, \mathrm{CDCl}_{3}\right.$, the TFPB numbering is reported in the S.I.) $\delta: 169.2$ (x4), 161.7 (q, J $50 \mathrm{~Hz}, \mathrm{C}-1), 161.5(\mathrm{x} 4), 136.2,134.8, \mathrm{C}-2), 129.7$ (x2), 129.0 (x2), 128.8 (x4), 128.8 (q, J $30 \mathrm{~Hz}, \mathrm{C}-3), 126.5$ (x4), 124.6 (q, J $270 \mathrm{~Hz}, \mathrm{C}-5), 117.4$ (C-4), 34.1 (x4), $30.1(x 4), 29.7(x 4), 27.3(x 3), 22.6(x 3), 22.3(x 2), 19.7(x 4), 14.0(x 4)$.

[7.2Na $]^{2+}$ 2TFPB - : white amorphous solid. ${ }^{1} \mathrm{H}$ NMR $\left(400 \mathrm{MHz}, \mathrm{CDCl}_{3}\right) \delta: 7.71(16 \mathrm{H}, \mathrm{s}, \mathrm{TFPB}-o-H)$, $7.53(8 \mathrm{H}, \mathrm{s}, \mathrm{TFPB}-p-H), 7.38(12 \mathrm{H}, \mathrm{bs}, \mathrm{Ar}-m-H$ and Ar- $-\mathrm{H}), 7.11(8 \mathrm{H}, \mathrm{d}, J 6.8 \mathrm{~Hz}, \mathrm{Ar}-o-H), 4.95(4 \mathrm{H}$, d, J $16.7 \mathrm{~Hz}, \mathrm{O}=\mathrm{C}-\mathrm{CHH}-\mathrm{N}-\mathrm{BBu}), 4.86(4 \mathrm{H}, \mathrm{d}, J 16.5 \mathrm{~Hz}, \mathrm{O}=\mathrm{C}-\mathrm{CHH}-\mathrm{N}-\mathrm{Bn}), 4.71(4 \mathrm{H}, \mathrm{d}, J 16.6 \mathrm{~Hz}$, N-CHH-Ph), $4.20(4 \mathrm{H}, \mathrm{d}, J 16.6 \mathrm{~Hz}, \mathrm{~N}-\mathrm{CHH}-\mathrm{Ph}), 3.62$ (4H, d, J $16.5 \mathrm{~Hz}, \mathrm{O}=\mathrm{C}-\mathrm{CHH}-\mathrm{N}-\mathrm{Bn}), 3.60(4 \mathrm{H}$, d, J $16.7 \mathrm{~Hz}, \mathrm{O}=\mathrm{C}-\mathrm{N}-\mathrm{CHH}-\mathrm{N}-\mathrm{iBu}), 2.97\left(4 \mathrm{H}, \mathrm{dd}, J 15.2\right.$ and $\left.7.7 \mathrm{~Hz}, \mathrm{~N}-\mathrm{CHH}-\mathrm{CH}\left(\mathrm{CH}_{3}\right)_{2}\right), 2.77(4 \mathrm{H}$, dd, J 15.2 and $\left.7.7 \mathrm{~Hz},-\mathrm{CHH}-\mathrm{CH}\left(\mathrm{CH}_{3}\right)_{2}\right), 1.50\left(4 \mathrm{H}, \mathrm{m}, \mathrm{N}-\mathrm{CH}_{2}-\mathrm{CH}\left(\mathrm{CH}_{3}\right)_{2}\right), 0.77(12 \mathrm{H}, \mathrm{d}, J 6.6 \mathrm{~Hz}$, $\left.\mathrm{N}-\mathrm{CH}_{2}-\mathrm{CH}\left(\mathrm{CH}_{3}\right)\left(\mathrm{CH}_{3}\right)\right), 0.65\left(12 \mathrm{H}, \mathrm{d}, J 6.6 \mathrm{~Hz},-\mathrm{CH}_{2}-\mathrm{CH}\left(\mathrm{CH}_{3}\right)\left(\mathrm{CH}_{3}\right)\right) .{ }^{13} \mathrm{C} \mathrm{NMR}:\left(100 \mathrm{MHz}, \mathrm{CDCl}_{3}\right.$, the TFPB numbering is reported in the S.I.) $8: 169.9$ (x4), 169.3 (x4), 161.7 (q, J $50 \mathrm{~Hz}, \mathrm{C}-1), 134.8$ (C-2), 
133.2 (x6), 129.6 (x6), 128.9 (q, J $30 \mathrm{~Hz}$ C-3), 126.5 (x6), 127.3 (x6), 124.7 (q, J $270 \mathrm{~Hz}, \mathrm{C}-5), 117.5$ (C-4), $55.9(x 4), 52.0(x 4), 48.1(x 8), 27.2(x 4), 19.7(x 4), 19.4(x 4)$.

$[8 \cdot 2 \mathrm{Na}]^{2+}$ 2TFPB - : white amorphous solid. ${ }^{1} \mathrm{H}$ NMR $\left(400 \mathrm{MHz}, \mathrm{CDCl}_{3}\right) \delta: 7.68(16 \mathrm{H}, \mathrm{s}, \mathrm{TFPB}-\mathrm{o}-\mathrm{H})$, $7.53(8 \mathrm{H}, \mathrm{s}, \mathrm{TFPB}-\mathrm{p}-\mathrm{H}), 4.88\left(4 \mathrm{H}, \mathrm{d}, J 16.8 \mathrm{~Hz}, \mathrm{O}=\mathrm{C}-\mathrm{CHH}-\mathrm{N}-\mathrm{CH}_{3}\right), 4.70(4 \mathrm{H}, \mathrm{d}, J 17.0 \mathrm{~Hz}$, $\left.\mathrm{O}=\mathrm{C}-\mathrm{CHH}-\mathrm{N}-\mathrm{CH}_{2} \mathrm{CH}_{2} \mathrm{CH}_{2} \mathrm{CH}_{2} \mathrm{CH}_{3}\right), 3.58\left(4 \mathrm{H}, \mathrm{d}, J 17.0 \mathrm{~Hz}, \mathrm{O}=\mathrm{C}-\mathrm{CH}-\mathrm{N}-\mathrm{CH}_{2} \mathrm{CH}_{2} \mathrm{CH}_{2} \mathrm{CH}_{2} \mathrm{CH}_{3}\right), 3.51$ $\left(4 \mathrm{H}, \mathrm{d}, \mathrm{J} 16.8 \mathrm{~Hz}, \mathrm{O}=\mathrm{C}-\mathrm{CH} H-\mathrm{N}-\mathrm{CH}_{3}\right), 3.26\left(4 \mathrm{H}, \mathrm{m}, \mathrm{O}=\mathrm{C}-\mathrm{CH}_{2}-\mathrm{N}-\mathrm{CHHCH}_{2} \mathrm{CH}_{2} \mathrm{CH}_{2} \mathrm{CH}_{3}\right), 3.03(4 \mathrm{H}, \mathrm{m}$, $\left.\mathrm{O}=\mathrm{C}-\mathrm{CH}_{2}-\mathrm{N}-\mathrm{CH} H \mathrm{CH}_{2} \mathrm{CH}_{2} \mathrm{CH}_{2} \mathrm{CH}_{3}\right), 2.88\left(12 \mathrm{H}, \mathrm{s}, \mathrm{O}=\mathrm{C}-\mathrm{CH}_{2}-\mathrm{N}-\mathrm{CH}_{3}\right), 1.59-1.48$ (8H, m, overlapping signals, $\left.\mathrm{O}=\mathrm{C}-\mathrm{CH}_{2}-\mathrm{N}-\mathrm{CH}_{2} \mathrm{CH}_{2} \mathrm{CH}_{2} \mathrm{CH}_{2} \mathrm{CH}_{3}\right), 1.26\left(16 \mathrm{H}, \mathrm{m}, \mathrm{O}=\mathrm{C}-\mathrm{CH}_{2}-\mathrm{N}-\mathrm{CH}_{2} \mathrm{CH}_{2} \mathrm{CH}_{2} \mathrm{CH}_{2} \mathrm{CH}_{3}\right), 0.87$ (12H, $\left.\mathrm{m}, \mathrm{O}=\mathrm{C}-\mathrm{CH}_{2}-\mathrm{N}-\mathrm{CH}_{2} \mathrm{CH}_{2} \mathrm{CH}_{2} \mathrm{CH}_{2} \mathrm{CH}_{3}\right) ;{ }^{13} \mathrm{C}-\mathrm{NMR}$ (100 MHz, CDCl 3 , the TFPB numbering is reported in the S.I.) $\delta: 170.3$ (x4), 168.8 (x4), 160.1 (q, J $50 \mathrm{~Hz}, \mathrm{C}-1), 136.4,134.8$ (C-2), 129.0 (q, J $30 \mathrm{~Hz}, \mathrm{C}-3)$, 124.6 (q, J 270 Hz, C-5), 117.6 (C-4), 50.2 (x4), 48.8 (x4), 45.5 (x4), 35.8 (x4), 29.7 (x4), 22.2 (x8), 13.6 (x4).

\subsection{5. ${ }^{1} \mathrm{H}$ NMR Variable Temperature Experiments}

The cyclopeptoid was dissolved in $\mathrm{C}_{2} \mathrm{D}_{2} \mathrm{Cl}_{4}$ (TCDE, $5.0 \mathrm{mM}$ solution), then ${ }^{1} \mathrm{H}$ NMR spectra were acquired at different temperatures, increasing 10 Kelvin each time. For compound 5 coalescence was observed at $383 \mathrm{~K}\left(\Delta G_{\mathrm{c}}^{\neq}=17.4 \pm 0.9 \mathrm{kcal} / \mathrm{mol}\right)$ for the signals at $3.66 \mathrm{ppm}$ and $2.32 \mathrm{ppm}$. For compound 6 coalescence was observed at $363 \mathrm{~K}\left(\Delta G_{\mathrm{C}}^{\neq}=15.9 \pm 0.8 \mathrm{kcal} / \mathrm{mol}\right)$ for the signals at $4.57 \mathrm{ppm}$ and $3.11 \mathrm{ppm}$. For compound 7 coalescence was observed at $363 \mathrm{~K}\left(\Delta G_{\mathrm{c}}^{f}=16.4 \pm 0.8 \mathrm{kcal} / \mathrm{mol}\right)$ for the signals at $5.25 \mathrm{ppm}$ and $3.72 \mathrm{ppm}$. The $\Delta G_{\mathrm{c}}^{\neq}$was evaluated according to the following relation:

$$
\Delta G_{\mathrm{c}}^{\neq}=a T_{c}\left[9.972+\log \left(\frac{T_{c}}{\sqrt{\Delta v^{2}+6 J^{2}}}\right)\right]
$$

where $T_{c}$ is the coalescence temperature, $\Delta v$ is the difference in Hertz between the two coupled signals and $J$ is the coupling constant between the two signals [42].

For compounds $[5-8 \cdot 2 \mathrm{Na}]^{2+} \cdot 2[\mathrm{TFPB}]^{2-}$ no coalescence was observed up to $383 \mathrm{~K}$.

\subsubsection{General Procedure for the Pirkle's Alcohol Addition to Racemic Mixture of Cyclopeptoid 7}

To a $5.0 \mathrm{mM}$ solution of cyclic peptoid 7 in $\mathrm{CDCl}_{3}(0.5 \mathrm{~mL}), 1.0$ equivalent of Pirkle's alcohol ((R)-1-(9-anthryl)-2,2,2-trifluoroethanol) was added. After the addition, the mixture was mixed for $1 \mathrm{~min}$ and the ${ }^{1} \mathrm{H}$ NMR spectrum was recorded. Further 1.0 equivalent of Pirkle's alcohol was added in order to increase the protons resonances' splitting. NMR spectra were recorded on a Bruker DRX $600\left({ }^{1} \mathrm{H}\right.$ at $\left.600.13 \mathrm{MHz}\right)$.

\subsection{Assay of Insecticidal Activity against Silkworm Larvae}

Third-instar larvae of silkworm Bombyx mori were purchased from Kougensha Co, Ltd. (Matsumoto, Japan) and cultured on an artificial diet SilkMate $2 \mathrm{~S}$ obtained from Nosan Corporation. Each compound dissolved or suspended in DMSO was injected into open vessels of 4th-instar larvae (mean body weight $c a 0.9 \mathrm{~g}$ ) resulting in the dose of $300 \mathrm{nmol} /$ larva. A total of 10 larvae were tested and the number of dead larvae was counted.

\subsection{Cell Lines and Viability Assay}

A375 (human melanoma) cells (American Type Culture Collection, Manassas, VA, USA) were maintained in DMEM supplemented with 10\% heat-inactivated foetal bovine serum (Invitrogen (Carslbad, CA, USA) in 5\% $\mathrm{CO}_{2}$ humid atmosphere. To ensure logarithmic growth, cells were subcultured every 2 days. The number of viable cells was determined by MTT conversion assay using [3-4,5-dimethyldiazol-2-yl]-2,5-diphenyl tetrazolium bromide (MTT, Sigma-Aldrich, Saint Louis, MO, USA). Briefly, A375 or A549 (3000/well) cells were seeded in triplicate in 96 well/plates and incubated with increasing concentrations of compounds 5-8 (between $5 \mu \mathrm{M}$ and $50 \mu \mathrm{M}$ ) or DMSO 
$0.10 \%(v / v)$ for $72 \mathrm{~h}$ in DMEM medium with 10\% FBS. Following the treatment, $20 \mu \mathrm{L}$ of MTT $\left(5 \mathrm{mg} / \mathrm{mL}\right.$ in PBS) was added and the cells were incubated for additional $3 \mathrm{~h}$ at $37^{\circ} \mathrm{C}$. The formazan crystals thus formed were dissolved in $100 \mu \mathrm{L}$ of buffer containing $50 \%(v / v) N, N$-dimethylformamide, $20 \%$ SDS ( $\mathrm{pH} 4.5$ ). The absorbance was measured at $570 \mathrm{~nm}$ with a Multiskan ${ }^{\mathrm{TM}}$ GO Microplate Spectrophotometer (Thermo Fisher Scientific, Waltham, MA, USA).

\section{Conclusions}

Understanding the conformational features of cyclooligoamides represents a necessary step to exploit their biological properties. In particular, the comprehension of their stereochemical traits is crucial, especially when the generation of rigid structures induces the formation of conformational enantiomorphs.

The isosteric transformation of bioactive cyclooctadepsipeptides in cyclooctapeptoids represents a simple way to explore the molecular space conjunct to macrocyclic oligoamides. Combined NMR and computational techniques allowed us to assign the structural identity of the formed species. The intrinsic conformational stability of cyclooctamer peptoids, in their free and complexed form, clarified their intricate topological features and evidenced possible detrimental effects on the binding interactions with target biomolecules and their scarce biological activities on silkworm larvae.

Differently from conformationally heterogeneous cyclohexapeptoids [10,12], cyclic octamer peptoids show limited capacity to mimic the natural counterparts. Although they are perfectly suited for solid-phase synthesis and combinatorial approaches to drug discovery, they show undesirable conformational and stereochemical complication that can decrease their adaptability to the molecular target.

Additional efforts are currently underway in order to design libraries of diverse and more malleable compounds that can exhibit increased biological properties and higher conformational mobility.

Supplementary Materials: The following are available online.

Author Contributions: A.D., F.D.R. and conceived and designed the experiments; A.D. and Y.M. performed the experiments; C.C. made the theoretical studies; I.I. and G.D.S. analysed the data; F.D.R. and Y.M. wrote the paper.

Funding: This research was funded by the University of Salerno (FARB), the Italian Ministero dell'Università e della Ricerca (MIUR) (PRIN 20109Z2XRJ_006), Regione Campania under POR Campania “FESR 2007-2013-O.O. 2.1 (FarmaBioNet)" and from POR CAMPANIA FESR 2007/2013 O.O.2.1.-CUP B46D14002660009 “Il potenziamento e la riqualificazione del sistema delle infrastrutture nel settore dell'istruzione, della formazione e della ricerca."

Acknowledgments: We thank Carmela Vaccaro and Ines Bruno (Department of Chemical and Pharmaceutical Sciences of the University of Salerno) for the cytotoxic tests.

Conflicts of Interest: The authors declare no conflict of interest.

\section{References}

1. Osbourn, A.E.; Lanzotti, V. (Eds.) Plant-Derived Natural Products: Synthesis, Function and Application; Springer: New York, NY, USA, 2009.

2. Wenders, P.A.; Miller, B.L. Synthesis at the molecular frontier. Nature 2009, 460, 197-201. [CrossRef] [PubMed]

3. Yoo, B.; Kirshenbaum, K. Peptois architectures: Elaboration, actuation and application. Curr. Opin. Chem. Biol. 2008, 12, 714-721. [CrossRef] [PubMed]

4. Fowler, S.A.; Blackwell, H.E. Structure-function relationships in peptoids: Recent advances toward deciphering the structural requirements for biological function. Org. Biomol. Chem. 2009, 7, 1508-1524. [CrossRef] [PubMed]

5. Zuckermann, R.N.; Kerr, J.M.; Kent, S.B.H.; Moos, W.H. Efficient method for the preparation of peptoids [oligo(N-substituted glycines)] by submonomer solid-phase synthesis. J. Am. Chem. Soc. 1992, 114, 10646-10647. [CrossRef]

6. Simon, R.J.; Kania, R.S.; Zuckermann, R.N.; Huebner, V.D.; Jewell, D.A.; Banville, S.; Ng, S.; Wang, L.; Rosenberg, S.; Merlowe, C.K. Peptoids: A modular approach to drug discovery. Proc. Natl. Acad. Sci. USA 1992, 89, 9367-9371. [CrossRef] [PubMed] 
7. Sun, J.; Zuckermann, R.N. Peptoid polymers: A highly designable bioinspired material. ACS Nano 2013, 7, 4715-4732. [CrossRef] [PubMed]

8. Zuckermann, R.N.; Kodadek, T. Peptoid as potential therapeutics. Curr. Opin. Mol. Ther. 2009, 11, $299-307$. [PubMed]

9. Webster, A.M.; Cobb, S.L. Recent advances in the synthesis of peptoid macrocycles. Chem. Eur. J. 2018, 24, 7560-7573. [CrossRef] [PubMed]

10. D'Amato, A.; Schettini, R.; Della Sala, G.; Costabile, C.; Tedesco Izzo, I.; De Riccardis, F. Conformational isomerism in cyclic peptoids and its specification. Org. Biomol. Chem. 2017, 15, 9932-9942. [CrossRef] [PubMed]

11. Yoo, B.; Shin, S.B.Y.; Huang, M.L.; Kirshenbaum, K. Peptoid macrocycles: Making the rounds with peptidomimetic oligomers. Chem. Eur. J. 2010, 16, 5528-5537. [CrossRef] [PubMed]

12. D'Amato, A.; Volpe, R.; Vaccaro, M.C.; Terracciano, S.; Bruno, I.; Tosolini, M.; Tedesco, C.; Pierri, G.; Tecilla, P.; Costabile, C.; et al. Cyclic peptoids as mycotoxins mimics: An exploration of their structural and biological properties. J. Org. Chem. 2017, 82, 8848-8863. [CrossRef] [PubMed]

13. Suzuki, A.; Kanaoka, M.; Isogai, A.; Murakoshi, S.; Ichinoe, M.; Tamura, S. Bassianolide, a new insecticidal cyclodepsipeptide from Beauveria bassiana and Verticillium lecanii. Tetrahedron Lett. 1977, 25, 2167-2170. [CrossRef]

14. Kanaoka, M.; Isogai, A.; Murakoshi, S.; Ichinoe, M.; Suzuki, A.; Tamura, S. Bassianolide, a new insecticidal cyclodepsipeptide from Beauveria bassiana and Verticillium lecanii. Agric. Biol. Chem. 1978, 43, 629-635. [CrossRef]

15. Shiomi, K.; Matsui, R.; Kakei, A.; Yamaguchi, Y.; Masuma, R.; Hatano, H.; Arai, N.; Isozaki, M.; Tanaka, H.; Kobayashi, S.; et al. Verticilide, a new ryanodine-binding inhibitor, produced by Verticillium sp. FKI-1033. J. Antibiot. 2010, 63, 77-82. [CrossRef] [PubMed]

16. Monma, S.; Sunazuka, T.; Nagai, K.; Arai, T.; Shiomi, K.; Matsui, R.; Ōmura, S. Verticilide: Elucidation of absolute configuration and total synthesis. Org. Lett. 2006, 8, 5601-5604. [CrossRef] [PubMed]

17. Sasaki, T.; Takagi, M.; Yaguchi, T.; Miyadoh, S.; Okada, T.; Koyama, M. A new anthelmintic cyclodepsipeptide, PF1022A. J. Antibiot. 1992, 45, 692-697. [CrossRef] [PubMed]

18. Sivanathan, S.; Scherkenbeck, J. Cyclodepsipeptides: A rich source of biologically active compounds for drug research. Molecules 2014, 19, 12368-12420. [CrossRef] [PubMed]

19. Süssmuth, R.; Müller, J.; Von Döhren, H.; Molnár, I. Fungal cyclooligomers depsipeptides: From classical biochemistry to combinatorial biosynthesis. Nat. Prod. Rep. 2011, 28, 99-124. [CrossRef] [PubMed]

20. Wang, X.; Gong, X.; Li, P.; Lai, D.; Zhou, L. Structural diversity and biological activities of cyclic depsipeptides from fungi. Molecules 2018, 23, 169. [CrossRef] [PubMed]

21. Krücken, J.; Harder, A.; Jeschke, P.; Holden-Dye, L.; O'Connor, V.; Welz, C.; von Samson-Himmelstjerna, G. Anthelmintic cyclooctadepsipeptides: Complex in structure and mode of action. Trends Parasitol. 2012, 28, 385-393. [CrossRef] [PubMed]

22. Harder, A.; Schmitt-Wrede, H.P.; Krücken, J.; Marinovski, P.; Wunderlich, F.; Willson, J.; Amliwala, K.; Holden-Dye, L.; Walker, R. Cyclooctadepsipeptides-an anthelmintically active class of compounds exhibiting a novel mode of action. Int. J. Antimicrob. Agents 2003, 22, 318-331. [CrossRef]

23. Greenberg, R.M. Ion channels and drug transporters as targets for anthelmintics. Curr. Clin. Microbiol. Rep. 2014, 1, 51-60. [CrossRef] [PubMed]

24. Masuda, Y.; Tanaka, R.; Kai, K.; Ganesan, A.; Doi, T. Total synthesis and biological evaluation of PF1171A, C, F and G, cyclic hexapeptides with insecticidal activity. J. Org. Chem. 2014, 79, 7844-7853. [CrossRef] [PubMed]

25. Masuda, Y.; Tanaka, R.; Ganesan, A.; Doi, T. Systematic analysis of relationship among 3D structure, bioactivity and membrane permeability of PF1171F, a cyclic hexapeptide with paralyzing effects on silkworms. J. Org. Chem. 2017, 82, 11447-11463. [CrossRef] [PubMed]

26. De Cola, C.; Fiorillo, G.; Meli, A.; Aime, S.; Gianolio, E.; Izzo, I.; De Riccardis, F. Gadolinium-binding cyclic hexapeptoids: Synthesis and relaxometric properties. Org. Biomol. Chem. 2014, 12, 424-431. [CrossRef] [PubMed]

27. Scherkenbeck, J.; Plant, A.; Harder, A.; Mencke, N. A highly efficient synthesis of the anthelmintic cyclooctadepsipeptide FP1022A. Tetrahedron 1995, 51, 8459-8470. [CrossRef] 
28. Dutton, F.E.; Lee, B.H.; Johnson, S.S.; Coscarelli, E.M.; Lee, P.H. Restricted Conformation Analogues of an Anthelmintic Cyclodepsipeptide. J. Med. Chem. 2003, 46, 2057-2073. [CrossRef] [PubMed]

29. Dale, J.; Titlestad, K. Cyclic oligopeptides of sarcosine (N-methylglycine). Chem. Commun. 1969, 656-659. [CrossRef]

30. Titlestad, K. Cyclic peptides of sarcosine. syntheses and conformation. Acta Chem. Scand. B 1975, 29, $153-167$. [CrossRef] [PubMed]

31. Lepage, M.L.; Meli, A.; Bodlenner, A.; Tarnus, C.; De Riccardis, F.; Izzo, I.; Compain, P. Synthesis of the first examples of iminosugar clusters based on cyclopeptoid cores. Beilstein J. Org. Chem. 2014, 10, 1406-1412. [CrossRef] [PubMed]

32. Vollrath, S.B.L.; Bräse, S.; Kirshenbaum, K. Twice tied tight: Enforcing conformational order in bicyclic peptoid oligomers. Chem. Sci. 2012, 3, 2726-2731. [CrossRef]

33. Vollrath, S.B.L.; Hu, C.; Bräse, S.; Kirshenbaum, K. Peptoid nanotubes: An oligomer macrocycle that reversibly sequesters water via single-crystal-to-single-crystal transformations. Chem. Commun. 2013, 49, 2317-2319. [CrossRef] [PubMed]

34. Tedesco, C.; Meli, A.; Macedi, E.; Iuliano, V.; Ricciardulli, A.G.; De Riccardis, F.; Vaughan, G.B.M.; Smith, V.J.; Barbour, L.J.; Izzo, I. Ring size effect on the solid state assembly of propargyl substituted hexa- and octacyclic peptoids. Cryst. Eng. Comm. 2016, 18, 8838-8848. [CrossRef]

35. Pirkle, W.H.; Beare, S.D. Optically active solvents in nuclear magnetic resonance spectroscopy. IX. Direct determinations of optical purities and correlations of absolute configurations of alpha.-amino acids. J. Am. Chem. Soc. 1969, 91, 5150-5155. [CrossRef]

36. De Cola, C.; Licen, S.; Comegna, D.; Cafaro, E.; Bifulco, G.; Izzo, I.; Tecilla, P.; De Riccardis, F. Size-dependent cation transport by cyclic $\alpha$-peptoid ion carriers. Org. Biomol. Chem. 2009, 7, 2851-2854. [CrossRef] [PubMed]

37. Fielding, L. Determination of Association Constants $\left(K_{\mathrm{a}}\right)$ from Solution NMR Data. Tetrahedron 2000, 56, 6151-6170. [CrossRef]

38. Meli, A.; Gambaro, S.; Costabile, C.; Talotta, C.; Della Sala, G.; Tecilla, P.; Milano, D.; Tosolini, M.; Izzo, I.; De Riccardis, F. Synthesis and complexing properties of cyclic benzylopeptoids-a new family of extended macrocyclic peptoids. Org. Biomol. Chem. 2016, 14, 9055-9062. [CrossRef] [PubMed]

39. Juvvadi, P.; Vunnam, S.; Merrifield, R.B. Synthetic Melittin, Its Enantio, Retro and Retroenantio Isomers and Selected Chimeric Analogs: Their Antibacterial, Hemolytic and Lipid Bilayer Action. J. Am. Chem. Soc. 1996, 118, 8989-8997. [CrossRef]

40. Shemyakin, M.M.; Ovchinnikov, Y.A.; Ivanov, V.T. Topochemical Investigations on Peptide Systems. Angew. Chem. Int. Ed. Engl. 1969, 8, 492-499. [CrossRef] [PubMed]

41. Ohshiro, T.; Matsudo, D.; Kazuhiro, T.; Uchida, R.; Nonaka, K.; Masuma, R.; Tomada, H. New verticilides, inhibitors of acyl-CoA: Cholesterol acyltransferase, produced by Verticillium sp. FKI-2679. J. Antibiot. 2012, 65, 255-262. [CrossRef] [PubMed]

42. Kurland, R.J.; Rubin, M.B.; Wise, M.B. Inversion Barrier in Singly Bridged Biphenyls. J. Chem. Phys. 1964, 40, 2426-2427. [CrossRef]

Sample Availability: Samples of the compounds 5, 7 and 8 are available from the authors.

(C) 2018 by the authors. Licensee MDPI, Basel, Switzerland. This article is an open access article distributed under the terms and conditions of the Creative Commons Attribution (CC BY) license (http://creativecommons.org/licenses/by/4.0/). 